\title{
Firm Performance and the Political Economy of Corporate Governance: Survey Evidence for Bulgaria, Hungary, Slovakia and Slovenia
}

\author{
By: Patrick Paul Walsh and Ciara Whelan
}

Working Paper Number 338

July 2000 


\section{Firm Performance and the Political Economy of Corporate G overnance:

\author{
Survey Evidencefor Bulgaria, Hungary, Slovakia and \\ Slovenia
}

By

\section{Patrick Paul Walsh* and Ciara Whelan**}

\footnotetext{
* The Transition Group, Department of Economics, Trinity College, Dublin and LICOS, Centre for Transition Economics, K.U. Leuven.

* The Department of Economics, University College Dublin and LICOS, Centre for Transition Economics, K.U. Leuven.
}

This paper was presented to the CEPR/WDI Conference Moscow in July 2000, the European Association for Research in Industrial Economics in September 1999 and the Dublin Economic Workshop in February 2000. We thank all participants for their comments. In addition many thanks are extended to Joep Konings for provision of the data and helpful comments and Frederic Warzynski for researching the extensive background literature. We acknowledge funding from Phare-Ace, Project 1997, 'The Impact of EU Trade on Firm Level Restructuring in Central and Eastern Europe'. 


\section{Non-Technical Summary}

The impact of privatisation on firm performance has generated a great deal of attention in transition economics. In particular, how did the new corporate governance structures that emerged in the transition process from centrally planned to market economies perform compared with state owned enterprises? Earlier empirical studies find that privatisation does not lead to better firm performance, while more recent studies find that only privatisation to outsiders is beneficial for performance. Most empirical studies to date develop a theme of insider rent seeking and corruption to explain the failure of privatisation to insiders to generate efficiency gains. In contrast to such a focus on political distortions, this paper provides strong evidence that insider privatisation is driven by political constraints, as modelled in Dewatripont and Roland (1995). Sequencing, or the gradual release of firms to outside ownership, is a market driven outcome, given the inherited market demand conditions that existed in Central Eastern Europe. It is part of a good and politically acceptable path that ensures the long-term success of the reform process.

An important emphasis in this paper is the role that inherited demand conditions play both in dictating the selection process of firms to privatisation, and on their subsequent performance. Within countries of CEE, strong trade links were developed with the EU. Coming out of planning firms inherited product lines designed to supply either the artificial CMEA market or the EU market. A detailed analysis of the Eurostat Trade data clearly illustrates, confirming the results of Rodrik (1994) and Repkine and Walsh (1999), that the reorientation of previously CMEA oriented products to the EU market was not an important feature of the transition period. Using survey data for Bulgaria, Hungary, Slovakia and Slovenia during the first seven years of transition, we examine the impact of various corporate governance structures on firm performance while controlling for the inherited demand conditions. The modelling of sequencing to outside ownership, the conditioning of our sequencing and performance regressions on the initial CMEA or EU trade orientation in 1988, and the inclusion of controls for time, country and narrowly defined sectors and regional locations of firms are all novel features of our empirical analysis in this paper. 
Controlling for other factors, we find that firms that produce historically EU oriented products consistently outperform firms that inherited products historically produced for the CMEA market during the first seven years of transition across our four CEE countries. We provide evidence that while CEE countries were eager to restructure the best firms in historically CMEA markets under outsider ownership, they resisted privatisation to outsider ownership in historically EU markets.

In historically CMEA markets, outsiders were given the best firms to restructure during transition, while the state and insiders maintained control of the loss making and politically sensitive firms across our CEE countries during the first seven years of transition. This was done to build political support for the restructuring of previously CMEA market. The more problematic loss making firms would be dealt with later.

The political economy of privatising EU trade oriented state firms was more in line with that observed in western economies. We show that the state and insiders in such firms were reluctant to privatise these highly viable and expanding firms to outsiders. Politically, it was more beneficial to retain control, undertake restructuring, and support reforms that developed a properly functioning stock exchange, which would eventually allow a successful public offering to outsiders. This was done to build political support from populations linked to the previously EU market. The more problematic issue of selling valuable assets to outsiders, for efficiency reasons, would naturally happen at a later date.

As a result of the different political constraints imposed on the selection process to outside ownership, the effect of corporate governance on firm performance was shown to be different among previously CMEA and EU trade oriented firms. Majority outside ownership outperforms majority insider/state ownership, but only when we condition our regression on initial CMEA trade orientation controlling for a gradualist selection process, pre- and post- privatisation effects, amongst other factors. This results from the political incentives to preserve loss-making firms in the short-run. Majority outside ownership does not outperform majority state/insider ownership when 
conditioned on initial EU trade orientation. This result is not surprising given the political resistance to giving the best EU oriented firms to outsiders and the fact that such firms are subcontracted by foreign licence, face upstream competition in their EU market, do not have liquidity constraints and inherited mangers with experience in global markets.

It is our thesis that political economy considerations induced insider profit maximising considerations in historically EU oriented firms and insider cost minimising considerations in historically CMEA oriented firms to have an important impact on the privatisation process and its subsequent impact on firm performance. Throughout this paper we have provided empirical evidence that political constraints driven by market demand considerations, rather than political distortions, have imposed themselves on the privatisation process and its subsequent impact on firm performance in Central Eastern Europe. Insider ownership is an important political outcome, driven by market demand considerations, that builds up political support for market reforms during its initial stages, ensuring their long-term success. 


\begin{abstract}
Using survey data for 220 traditional manufacturing firms over 7 years of transition and $4 \mathrm{CEE}$ countries, we find firms that produced for the EU market under planning consistently outperform those that produced for the CMEA market. Within the previously CMEA market, the best firms were selected to outside privatisation and outperformed insider/state owned firms. Outside privatisation was resisted in EU oriented firms and ownership was found to have no effect on performance. We argue that insider/state ownership in previously CMEA and EU markets builds up political support for the market system during its initial stages, ensuring its long-term success.
\end{abstract}

Keywords: Firm Performance, Political Economy, Privatisation and Demand Shocks. JEL Classification: $\quad \mathrm{P} 52$ 


\section{Introduction}

The impact of privatisation on economic performance in transition countries has generated much interest. Stiglitz (1999) portrays the general consensus that mass privatisation, within a complementary package of "big bang" reforms, seems to have failed to generate the expected efficiency gains across transition countries. ${ }^{\text {One outcome }}$ of the privatisation programmes was that they somehow generated a bias towards insider (worker and manager) ownership. Boycko, Shleifer and Vishny $(1994,1996)$ argue that the allocation of property rights to inside control was an attempt by government to gain political support during privatisation which, as a consequence, in terms of economic efficiency, lead to the failure of the privatisation process. Most empirical studies develop this theme of insider rent seeking and corruption to explain this perceived empirical failure of insider privatisation. Such political distortions may be an accurate description of the situation in Russia. However, in the Countries of Central Eastern Europe (CEE), we provide empirical evidence that insider ownership is an important political outcome that builds up political support for the privatisation process during its initial stages, and ensures its long-term success. As modelled in Dewatripont and Roland (1995), we argue that a gradual release of firms to outside ownership is a market driven outcome, given the inherited market demand conditions that existed in CEE and political constraints. This is a politically acceptable path that ensures the long-term success of the reform process. We show that political constraints, driven by inherited market demand conditions, have imposed themselves on the privatisation process and its subsequent impact on firm performance in CEE during the early days of transition. We do this using survey evidence for Bulgaria, Hungary, Slovakia and Slovenia during the first seven years of transition

The role of initial demand conditions on firm performance and ownership structure during the transition period is emphasised in this paper. Compared to CIS countries, CEE countries over the 1970s and 1980s developed strong trade links with the EU. Coming out of planning state firms inherited production lines designed to supply either the artificial CMEA market or the EU market. Due to a focus on scale economies and specialisation under central planning each country inherited different clusters of large monopolies producing for the EU and CMEA markets. Repkine and Walsh (1999) highlight the importance of these inherited demand conditions in determining the evolution of industrial output. They document the presence of exports to the EU in all 
NACE Rev. 1 manufacturing sectors in Bulgaria, Hungary, Poland and Romania in 1988, and the extreme clustering of such within sectors into certain 5-digit products. Modelling the dynamics of industrial output across sectors of these countries, they estimate the recovery in industrial output to be driven by EU oriented output over the period 1990-96, within the same clustering of manufacturing products that were exported before transition in 1988. Alongside these developments, they estimate a continual decline of previously CMEA oriented output by sector of industry in each country. This is consistent with the data on exports, Hoekman and Djankov (1997), that documents the rapid decline in previously CMEA oriented trade and expansion in EU oriented trade in the first few years of transition up to 1996. Repkine and Walsh (1999) illustrate that the U-shape experience of industrial sectors across CEE countries resulted from path dependent investment demand shocks that induced a rapid decline in products traditionally producing for the CMEA market and a gradual expansion in products traditionally producing for EU market. The role of demand shocks challenges the thesis that supply side distortions were the sole determinants of the evolution of industrial output in CEE countries.[?

Given the findings of Repkine and Walsh (1999), one might expect the ownership structures and the performance of firms operating in historically CMEA trade oriented production to be different compared to that observed in firms inheriting EU trade oriented production. The novelty of this paper is to examine the effects of inherited demand conditions on firm performance both directly and indirectly via their impact on corporate ownership. We provide evidence that initial demand conditions have a direct impact on firm performance during transition. Controlling for other factors, firms that produce EU oriented products consistently outperform firms that inherited products historically produced for the CMEA market during the first seven years of transition across our four CEE countries. This is due to the very different underlying conditions and growth prospects of these firms coming out of planning. In addition, inherited demand conditions impose interesting political constraints on the ownership structures of firms during transition. The presence of two fundamentally different species of firms under central planning is shown to have important implications for the political economy of corporate governance and its impact on performance in Central Eastern Europe.

Within the artificially nurtured CMEA market, at the start of transition, some non-viable and inefficient firms will eventually have to exit, while those with long- 
term viability are likely to have to undertake some degrees of restructuring during transition. This is aptly summarised in the following: "Among production activities, changes in relative prices and the loss of CMEA markets, imply that some are and will remain loss making and must therefore be closed. The others may be viable, but not without labour shedding and the infusion of new, more modern capital" [Aghion, Blanchard and Burgess (1994), pp. 1330]. We provide evidence that CEE countries undertook a gradualist approach to privatisation, in the manner modelled by Dewatripont and Roland (1995), in historically CMEA markets. Building on the seminal work of Alesina (1987), they model a politically acceptable way of inducing reforms that are necessary in the transition to a market economy but have an overall negative expected outcome on the population ex-ante. Reforms yielding positive effects should be implemented first. The more painful reforms, necessary to sustain benefits from initial reforms in the long run and avoid reversal costs, become politically easier to implement at a later stage. "This is the effect of building constituencies, using the 'sweet pill' of early reforms to have the population swallow the 'bitter pill' of less popular reforms" [Roland, 1993, pp. 535]. In relation to privatisation of previously CMEA firms therefore, sequencing is predicted where the best enterprises needing restructuring with long-term growth opportunities should be privatised first. The closing down or imposition of hard budget constraints on lossmaking previously CMEA firms should come at a later stage. We provide evidence that CEE governments allowed such a gradualist approach in the privatisation of previously CMEA firms. We show that in the previously CMEA market outsiders were given the best firms to restructure during transition, while the state and insiders maintained control of the loss making and politically sensitive firms across our CEE countries during the early periods of transition.

In contrast, within the historical EU market, at the start of transition, firms/workers inherited very different demand conditions. They produced viable highquality goods at low cost, historically sold into competitive upstream markets, and subcontracted by western firms. Such firms operated in high growth areas and did not require a lot of restructuring or finance in order to survive the transition process to a market economy. The political economy of privatising EU trade oriented firms is more in line with that observed in western economies. We show that the state and insiders in firms were reluctant to privatise highly viable and expanding firms to outsiders in the early days of transition. ${ }^{4}$ Politically it was more beneficial to retain 
control, undertake restructuring, and wait until the economy is more developed with a properly functioning stock exchange that would allow a successful public offering. f́ln relation to political economy of privatising previously EU firms therefore, sequencing is recommended where enterprises with growth opportunities should be allowed to wait before pursuing efficiency gains from outside ownership. The imposition of outside ownership on profit making previously EU firms should come at a later stage.

Inside/State ownership allowed issues such as bankruptcy of out-dated CMEA firms and the transfer of profitable EU oriented firms to outsiders to be dealt with at a later date thus ensuring political acceptability of the initial reforms. As a result of the different sequencing processes of firms for outside privatisation, the effect of corporate governance on performance is different between previously CMEA and EU trade oriented firms. A large literature exists on the effects of privatisation on firm performance both for western and transition economies. ${ }_{6}^{6}$ While the results are mixed,

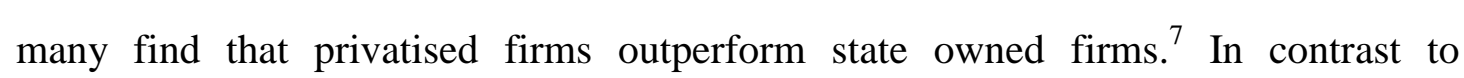
Frydman, Gray, Hessel and Rapaczynski (1999), we condition our firm performance regression on a privatisation sequencing process, both conditioned on initial trade orientation, while allowing for pre- and post- privatisation effects, amongst other factors. We estimate for our sub-sample of firms inheriting CMEA trade oriented production from central planning, even when allowing for sequencing in the selection process, that majority outside ownership outperforms majority insider ownership. 8 State and insider owned under performed relative to the outside owned firms due to the political incentives to preserve, with soft budget constraints, loss making firms in the short run [Kornai 1988, Berglof and Roland 1998]. This strategy was undertaken to gain long term political support for the restructuring process in the previously CMEA market, [Dewatripont and Roland (1995)].

In contrast, we estimate for our subsample of firms inheriting EU trade oriented production from central planning, that majority outside ownership did not outperform majority state or insider ownership. Given the political resistance to giving the best EU oriented firms to outsiders and the fact that such firms are subcontracted by foreign licence, face upstream competition in their EU market, inherited mangers with experience in global markets with no liquidity constraints, this result should not be surprising. If complete and enforceable contracts can be written between foreign and home firms then privatisation should have no significant effect on performance [Hart, 
Shleifer and Vishny1997, Shleifer 1998]. Moreover, competition is documented to be as effective as privatisation as a means of reforming state owned enterprises [Yarrow 1986, Kay and Thompson 1986, Vickers and Yarrow 1988, Bishop and Kay 1989, Beesley and Littlechild 1989, Caves 1990]. Finally, incumbent managers, for external finance reasons, had good incentives to engage in the development of their firm, which contrasts strongly with the incentives faced by insider mangers in loss making previously CMEA firms, [Roland 1996]. Hence, the positive effect on firm performance from privatisation is not found when regressions are conditioned on initial EU trade orientation, amongst other factors. State and insider control of viable firms can be seen as a strategy that gained long term political support for the restructuring process in the previously EU market. While insider/state ownership minimised the losses in populations linked to previously CMEA oriented firms; it maximised gains in populations linked to previously EU oriented firms. This had the effect of building up political support for the market system during its initial stages, ensuring its long-term success.

Frydman, Gray, Hessel and Rapaczynski (1999) in their empirical work claim to support the theoretical literature that see insider privatisation is a political distortion that blocks the long-run success of the market system during transition. One has to condition firm performance and the selection process to privatisation on initial trade orientation, among other factors, to have an accurate interpretation of the role of insider ownership in CEE countries. As modelled in Dewatripont and Roland (1995), we argue that a gradual release of firms to outside ownership should be an expected outcome of market forces under political constraints. Given the inherited market demand conditions that existed in $\mathrm{CEE}$, it is the only politically acceptable path that ensures the long-term success of the reform process. Political constraints, and not distortions, driven by market demand considerations, have imposed themselves on the privatisation process and its subsequent impact on firm performance in Central Eastern Europe during the early days of transition.

Section II describes how we determine the historical trade orientation of firms. Section III provides a detailed description of the LICOS survey data used in our empirical analysis. The empirical modelling of the selection process to privatisation and firm performance is undertaken in section IV. The final section of the paper concludes. 


\section{Historical Trade Orientation of Firms}

The EUROSTAT TRADE STATISTICS database is a high quality database providing annual data on trade flows by product categories between the European Union and some 200 non-European Union countries. From this database, we obtained data on

exports to the EU from Bulgaria, Hungary, Solvenia, and Slovakia in $1988 .{ }^{0}$ These export flows were retrieved in thousands of ECUs at the 3-digit NACE-CLIO product level, the lowest level of aggregation compatible with our survey data, and at the corresponding broad NACE Rev. 1 sector levels. A list of these 14 1-digit sectors and their CLIO 3 product components are highlighted in Table 1. Using these data we classify products on the basis of their historical trade orientation. Virtually all CLIO 3digit products in 1988 exhibit some level of exports to the EU, but within broad sectors these are highly concentrated in a small number of products. Hence the criteria for classification of products by trade orientation is based on a Concentration Ratio of export flows to the EU. Products within 1-digit sectors of each country that account for the cumulative top 98 per cent of exports to the EU in 1988 are considered EU trade oriented products. Products exhibiting either no exports to the EU or accounting for an insignificant share of sector exports in 1988 are classified as being CMEA oriented products under the central planning regime.

Table 1 details the classified trade orientation of 3-digit NACE-CLIO products for each country based on our criteria. While in many instances the trade orientation of products is similar over each of the countries in our analysis, there are also some marked differences. In the Food, Beverage and Tobacco sector for example, the Mineral Water and Soft Drinks product category (CLIO 427) is only considered EU trade oriented in Slovakia, while Animal and Poultry feedings (CLIO 422) is EU trade oriented in all countries except Slovakia.

Table 2a reports the percentage of CLIO 3-digit product categories in a sector that are classified as being EU trade oriented by country in 1988. While all manufacturing sectors exhibit some degree of trade with the European Union in 1988, for many sectors this is fairly clustered within 3-digit products. For example, only 26 per cent of products in the Food, Beverage and Tobacco sector of Bulgaria and Hungary explain 98 per cent of its total exports to the EU. Table $2 \mathrm{~b}$ documents the annual average growth in sector exports over the period 1988 through to 1996. All sectors over time in each of the countries exhibit positive growth in exports to the EU, although clearly inter- 
sectoral differences emerge. Despite the explosion in exports to the EU, exports remain within the same clustering of manufacturing products that exported to the EU before transition. The degree of persistence in product exports over time is indicated in Table 2c, which describes the share of 1996 exports accounted for by those products identified as being EU oriented in 1988. Invariably, 1996 exports of products that were traditionally EU trade oriented under central planning explain fully or the vast majority of EU exports in 1996 Confirming the results of Rodrik (1994), the reorientation of previously CMEA oriented products to the EU market was not an important feature of the transition period. These findings mirror those of Repkine and Walsh (1999).

The survey data do not enquire into the historical markets of traditional firms. Yet, we do know the CLIO 3-digit product category of traditional firms, which can be identified as historically EU or CMEA trade oriented product during the planning regime. The specialisation of large monopoly firms in products and markets, a core feature of planning, ensures that the tagging of firms into historical markets by their CLIO 3-digit product category proves to be a sensible control for a firms initial trade orientation.

\section{Data Description}

\section{Overview of the Data}

The core data used in our analysis are derived from the LICOS firm level surveys conducted in early 1997, which provides detailed firm level information for Bulgaria, Hungary, Slovakia and Slovenia. 11 This database was compiled on the basis of personal interviews with the general manager and/or some other key managers of 513 individual firms over our candidate countries. The firms were selected from different business registers as well as from address books and databases from local research institutes, and included a stratified sample of 50 per cent de novo firms in manufacturing, trade and services and 50 per cent traditional firms, mainly selected from the manufacturing sector. De novo firms are those that have been private since establishment and began operation after 1989, while traditional firms describe those that existed under central planning. 12

In this paper we are solely interested in analysing the relative performance of traditional manufacturing firms by different ownership types. We obtain a cross-section of 220 traditional manufacturing firms for Bulgaria (68 firms), Hungary (67 firms), 
Slovakia (48 firms), and Solvenia (37 firms) which successfully survived the transition process to a market economy and were still operating at the time of the survey.

These traditional manufacturing firms provide detailed information on their ownership structure in 1996. This enables us to examine the issues of corporate governance. Firms are classified by region according to the level-3 Nomenclature of Territorial Units for Statistics (NUTS). In addition, firms are classified by 3-digit NACECLIO code on the basis of their main production. Knowledge of the primary product categories in which a firm produces allows us to identify whether it inherited EU or CMEA oriented production from the central planning regime on the basis of our analysis in the previous section.

The survey asks retrospective questions on employment levels, dating back to 1990. While some firms do not report employment for the earlier years, the resultant database is extremely rich: an unbalanced panel of 220 traditional manufacturing firms over 7 years and 4 CEE countries with detailed information on employment, ownership, regional and product classification. Before turning to our microanalysis of these data, we first assess whether the data are representative of the manufacturing sector in terms of official statistics on the evolution of manufacturing employment in each of our candidate countries.

\section{The Evolution of Manufacturing Employment}

Industrial employment data by NACE Rev. 1 sectors of manufacturing is obtained from official statistical yearbooks. Table 3 describes the actual evolution of manufacturing employment in each of our 4 countries over time using an index of these data, where employment is normalised by initial manufacturing employment in 1991. With the exception of Bulgaria, the trend over the other CEE countries is one of declining employment at a decreasing rate over time. This can be compared with the evolution of manufacturing employment for the 220 firms in our survey, which accounts for 10 per cent of 1996 total manufacturing employment in these countries. We observe similar trends for each of the countries, but the rate of decline in the firms surveyed is lower than the actual rate of decline in the country. Examining the evolution of employment for CMEA compared with EU trade oriented firms in our survey, it is clear that while both follow the overall trend in employment, the rate of decline is greater for CMEA oriented firms. Firms that historically traded with the EU under central planning 
clearly outperform those previously oriented to CMEA in terms of employment. In the case of Slovenia for example, by 1996 manufacturing employment in CMEA firms declined to 63 per cent of its 1991 level while that of EU oriented firms fell only to 90 per cent. The differential between the employment performance of CMEA and EU oriented firms and the overall lower decline in our survey data compared with actual employment trends indicates a bias in our sample towards surviving EU oriented firms. This is evident in table 4.

\section{Sector and Trade Orientation of Survey Sample}

A decomposition of data by sector and initial trade orientation of products within the 14 broad sectors of manufacturing for each of our candidate countries is provided in Table 4. Examining firstly the total number of firms in each country by sector, it becomes apparent that there is a reasonably good spread of surveyed firms over the 14 broad sectors of manufacturing. With few exceptions, every sector is represented in each country with some inter-country and inter-sector variation. The percentage of EU trade oriented firms (70 per cent overall) is highest in Slovakia (80 per cent) and lowest for Hungary (64 per cent). While the EU oriented firms tend to have a good spread over manufacturing sectors in general, CMEA oriented firms tend to be more clustered into traditional sectors such as the Food, Beverage and Tobacco sector.

\section{Regional Dimensions of Surveyed Firms}

Regional differences in factor endowments, infrastructure and distance from EU borders can result in differences in firm performance. Thus, while the speed and success of firm restructuring in industrial sectors is dependent on the inherited trade orientation of firms, in addition it may depend on regional specific factors. For this reason, it is important to explicitly control for regional differences in the location of firms when analysing ownership and performance in the transition to a market economy. Table 5 illustrates the regional classifications according to the level-3 Nomenclature of Territorial Units for Statistics (NUTS) available from Eurostat, and the distribution of firms over these regions. Virtually all regions are represented in our sample. Moreover firms in general and by trade orientation can be seen to have a good geographical spread. 


\section{Corporate Structures of Surveyed Firms}

The three main methods of privatisation include public offering through share issue, asset sales and mass privatisation. In contrast to western economies, privatisation in transition countries tends to be restricted to either asset sales or mass privatisation programmes due to the low stock of private savings [Estrin, 1994] and the absence of a developed stock exchange [Megginson, Nash, Netter and Poulsen 1998]. Mass privatisation programmes, involving the transfer of vouchers into private hands for the purchase of state assets, were initiated in waves in Bulgaria and Slovakia in 1995 and 1992, respectively, and continuously in Slovenia in 1994. ${ }^{13}$ Privatisation in Hungary was undertaken by asset sales in three phases, "Top down sales" in 1990, where the government selected the firms, "Bottom up sales" in 1991-92, where firms selected themselves and a final phase "Bottom up sales" from 1993 that focused on asset sales to domestic outsiders. In all cases either the state or insiders dictated the selection of firms for privatisation to outsiders. Pohl, Anderson, Claessens and Djankov (1997), using 6,300 firms across seven CEE countries during the period 1990-95, while controlling for the fact that the best firms were selected first, find the method of privatisation (voucher or asset sale) did not effect the likelihood of a firm undertaking successful restructuring. For these reasons we model the ownership structures observed across our countries as an outcome of initial trade orientation and sequencing issues, amongst other factors. The country specific privatisation programmes are not considered formally, but are implicitly controlled for by the inclusion of country dummies in our selection and growth equations.

Detailed information on the ownership structure of surveyed firms in 1996 enables us to classify firms by majority ownership type. State owned enterprises is defined in World Bank (1995) as "government-owned or government-controlled economic entities that generate the bulk of their revenues from selling good and services". We model state owned as 50 per cent or more majority state ownership. The state often retains a significant and often decisive influence in privatised firms in transition economies. ${ }^{14}$ Even after privatising, the state invariably retains some control of the firm as a consequence of the firm being cash starved [Bolton and Roland 1992, Sinn and Sinn 1993] or a desire for risk sharing in order to induce greater restructuring by the private holder [Bennet and Maw 1998, Demougin and Sinn 1994, Cornelli and Li 1994]. Thus, partial state participation is a phenomenon of transition economies and our data. 
When majority control is in the hands of managers or workers we define the firm to have majority insider ownership, as defined in the literature. When majority control is in the hands of foreign or other domestic owners we define the firm to have majority outside ownership. The governance structures in 1996 of the firms in our sample are defined on the basis of the above classifications. Firms are grouped into their endpoint ownership structure in the analysis of their performance over the transition period. As in Frydman, Gray, Hessel and Rapaczynski (1999), we assume that firms selected to state, inside or outsider ownership in 1996 have unobservable group characteristics, or fixed effects, that impacts firm growth over the entire transition period and not just from the date of privatisation. This controls for both pre- and post- privatisation effects in our empirical modelling.

Table 6 decomposes our sample of firms by ownership status and trade orientation in 1996. Overall, we have 35 per cent state owned traditional firms, with 40 and 25 per cent respectively being classified as majority outsider and insider owned. These relative shares by ownership type are similar for both traditionally EU and CMEA oriented firms, and so there is a good representation of each type of firm in our sample.

\section{Employment Size and Firm Growth}

In this paper we measure firm performance in terms of employment growth. This circumvents many of the difficulties inherent in measuring performance in terms of revenue, productivity or profitability in transition economies. ${ }^{-15}$ The employment effects of the privatisation process is a crucial policy variable. Retrospective questions on employment size provide us with details of total numbers employed by firms from 1990 through to 1996. The effect of privatisation on employment across various countries has tended to have an ambiguous effect. Boubakri and Cosset (1998) find that privatisation of firms in developing countries improves performance measures in terms of employment. On the other hand, D'Souza and Megginson (1998) find that privatisation reduces employment in both developing and developed countries. Frydman, Gray, Hessel and Rapaczynski (1999) find no employment effects from privatisation in CEE transition countries.

The summary statistics on average firm size and employment growth over the transition period grouped by ownership type in 1996 and trade orientation in 1988 are presented in Table 7 both for the initial and later years. We note that the sample consists 
of large firms that were continually downsizing over the first seven years of transition. In our regression analysis we will need to control for the effects of downsizing. This is particularly true for firms selected to majority outsider control by 1996, which tend to be larger on average than firms that remain state over the period in question. Taking the CMEA oriented firms, it is clear in the raw data, that firms selected to outsider control perform better than either firms selected to insider control or those that remained in state hands in 1996. This is very evident in the initial period, when the average growth of outsider firms is -0.02 , as compared with -0.11 and -0.12 for insider and state owned firms respectively. Regarding the EU trade oriented firms, the performance of firms over transition does not seem to differ dramatically over the different ownership groups observed in 1996. In the latter period of transition, the average growth rates are -0.02 , 0.01 and -0.03 for majority state, outsider and insider firms, respectively. These statistics are in line with the theoretical predictions outlined in the opening section of this paper. Privatisation to outsiders in the previously CMEA trade oriented firms seems to have had a better employment performance when compared to the state or insider owned firms during the transition period. No significant effect of ownership structure on the evolution of employment is observed during transition in historically EU trade oriented firms. We now proceed to verify these conclusions in an econometric model that controls for sample selection issues amongst other time, country, sector and region specific factors.

\section{Empirical Modelling}

In this section we undertake an empirical modelling of firm performance and the political economy of corporate governance for traditional manufacturing firms in Bulgaria, Hungary, Slovakia and Slovenia. This analysis extends the approach taken in Frydman, Gray, Hessel and Rapaczynski (1999). They use a sample of 218 small and medium traditional firms for the period 1990 through 1994 in Poland, Hungary and the Czech Republic, to examine the effects of insider and outsider ownership on various measures of firm performance, including employment. They control for pre-and post privatisation effects on firm growth using group effects, as in this paper. We extend their analysis of insider and outsider corporate governance by using a richer panel database on 220 traditional manufacturing firms spanning CEE countries over a longer time span, 1990 through 1996. The novel features of our approach include the modelling of sequencing to outside ownership in 1996, the conditioning of our sequencing and 
performance regressions on the initial trade orientation of firms in 1988, and the inclusion of controls for time, country and narrowly defined sectors and regional locations of firms. These novelties have a significant impact on our results and add to our understanding of the impact of ownership structures on firm performance during the early stages of transition in CEE countries. In particular, insider ownership should not be seen as a bad thing, per se, but rather an outcome of market forces and political constraints that ensures the long-term success of the privatisation programme.

\section{The Selection Process to Privatisation}

We now proceed to empirically model the selection process to ownership groups in 1996. Our key explanatory variables include a dummy for inherited trade orientation in 1988 and sequencing effects, among other factors. To capture the effect of the best firms being selected for privatisation first, we include the employment growth rate of a firm in an early period of transition, 1991-1992. Most firms in our sample were state owned during this period, the exception being a few firms that may have been involved in the first wave in Hungary. Thus we estimate the probability of firms being privatised in 1996 in the following equation,

$$
\text { Ownership }_{i, 96}=\beta_{0}+\beta_{2} \text { Growth }_{i, t-4}+\beta_{3} \text { Trade }_{i}+\beta_{4} \text { Controls }+\varepsilon_{i}
$$

The ownership structure firms is defined for 1996. The growth performance in 1992, rather than 1991, is selected since this has the advantage of maximising the number of survey responses while allowing three years for state firms to restructure during transition. Following the growth of firms literature, in the spirit of Davis and Haltwinger (1992), we compute growth in a discrete way for firm i, bounded in the interval -2 and +2 , by the following,

$$
\text { Growth }_{i t}=\frac{E m p_{t}-E m p_{t-1}}{\left(E m p_{t}+E m p_{t-1}\right) / 2}
$$

The variable Trade indicates the trade orientation that the firm inherits from central planning. This is equal to 1 where firms are primarily producing in NACE CLIO 3-digit products that exported to the EU in 1988, as described in section II of the paper. Other controls include country and regional level-3 NUTS dummies. It is very important to control for regions in modelling the selection process to privatisation given the regional differences in development. Since ownership structures do not vary greatly 
within individual 3-digit products but there are variations in ownership structures across broader sectors, we include sector controls at the 1-digit level.

The first specification of this model defines Ownership equal to 1 where firms are majority privatised (insider or outsider) in 1996 and 0 otherwise. The results of the logit regression are presented in the first column of Table 8.16 The overall explanatory power of the model is high, $\mathrm{R}^{2}$ of 0.63 . Although not reported, country, sector and regional controls are strongly significant indicating differences in the probability of a firm being privatised over these variables. For example, compared to the default category, Bulgaria, firms are more likely to be privatised in each of the other candidate countries.

The inherited trade orientation of firms has a negative and significant, at the 5 per cent level, effect on the selection process. This indicates that firms that were previously EU trade oriented under central planning are less likely to be privatised by 1996. The state is less likely to privatise highly viable and expanding firms compared to previously CMEA trade oriented firms that require restructuring. As highlighted in the introduction, they find it more profitable to retain control of the EU oriented firms, undertake restructuring, and wait until the economy is more developed with a properly functioning stock exchange to allow a successful public offering.

The probability of being privatised is positively related to firm performance in the early years of transition, but only in the subsample of CMEA firms. This sequencing effect is completely offset in our subsample of EU oriented firms. Within the previously CMEA market there was a sequencing of firms in the privatisation process, with the best performers more likely to be privatised first. In contrast, there is no apparent sequencing in the privatisation of historically EU trade oriented firms, where all firms seem equally viable but collectively less likely to be privatised when compared to historically CMEA firms.

The second specification of the selection model decomposes the average ownership effect further into majority insider and outsider ownership. The results of this multinomial logit regression analysis are presented in the final two columns of Table 8 , which illustrate the probability of firms being outsider or insider controlled in 1996 compared with the benchmark case of majority state ownership. Rather interesting results emerge. Column 2 reports the probability of firms being outsider owned compared to state owned in 1996. CMEA firms are more likely to be privatised to 
outsiders than EU oriented firms, and there is apparent sequencing in the privatisation of CMEA firms to outsiders, as the best performers in 1992 had a higher probability of being selected. In contrast, there is no apparent sequencing in the privatisation of EU trade oriented firms to outsiders.

These results contrast greatly with those relating to the probability of firms being majority insider owned in 1996 when compared with the benchmark case of majority state ownership. In column 3 of Table 8 we observe evidence of sequencing in privatisation, irrespective of the inherited trade orientation of firms. Firms that perform better relative to state firms in 1992 are more likely to be selected to insider control irrespective of trade orientation. In addition trade orientation is not an important factor in the selection of state firms to insider ownership during transition.

These results suggest that the state and insiders did not have a desire to release control of the EU trade oriented firms during transition. They prefer to wait until the stock exchange is adequately developed to ensure a maximum return for these profitable firms in a public share offering. In contrast the state and insiders did have a preference to retain control of poor performing firms with a previously CMEA orientation. Such insider/state control across markets was done to minimise the losses of populations involved in previously CMEA markets and maximise the gains of populations historical involved in EU markets. Given market demand considerations, these outcomes paved a politically acceptable path for the reforms during the early days of transition and ensured long term political support for privatisation and the market system.

\section{Firm Performance, Ownership and Trade Orientation}

We are now in a position to model firm performance, in terms of employment, during the period 1990-96 across our 4 CEE countries. The basic growth model we estimate is as follows,

$$
\begin{aligned}
\text { Growth }_{i t}= & \beta_{0}+\beta_{1} \text { Initial Size }_{i}+\beta_{2} \text { Ownership }_{i, 96}+ \\
& \beta_{3} \text { Trade }_{i}+\beta_{4} \text { Controls }_{+} \varepsilon_{i}
\end{aligned}
$$

The employment growth of firm $i$ is computed once again as in (2), where $t$ is defined annually from 1991 through to 1996. From Table 7 the need to control for firm downsizing becomes apparent, and so we include Initial Size $e_{i}$ which measures the size of firm in 1990. We firstly examine the average effects of firm types grouped by ownership structure in 1996, Ownership ${ }_{i, 96 .}$, on firm performance during the transition period, which 
controls for pre-and post-privatisation fixed effects of our firm groupings. Ownership is initially defined as being equal to 1 when a firm is majority private owned and 0 when majority state owned. We first estimate the average effect of privatisation. We initially take ownership structure as a given variable, an assumption that is relaxed later when we instrument ownership structure using the predicted values obtained from our selection equations reported in Table 8. The variable Trade indicates the trade orientation that the firm inherits from central planning as before, being equal to 1 in the case of EU trade oriented and zero otherwise. Controls include country, year, 3-digit product, and regional level-3 NUTS dummies. The results of various specifications of this model are given in Table 9.

The first column reports the results without conditioning our independent variables on the inherited trade orientation of firms. Country, year, regional and product controls, although not reported here, are highly significant factors in determining firm performance. Initial size is not statistically significant. What is of primary interest is the fact that majority privatised firms do not perform significantly better than state owned. In the second column we introduce the trade orientation of firms in 1988. Neither ownership nor inherited trade orientation is significant at the 5 per cent level. This specification however, fails to recognise that the impact of ownership on firm performance may depend on the trade orientation, EU versus CMEA, of firms. In column three we condition each of our independent variables on the inherited trade orientation of firms. The results are striking. Firms that are EU trade oriented perform significantly better than those firms producing products that were previously direct to the CMEA. Ownership is now positive and significant at the 5 per cent level for the subsample of CMEA oriented firms - privatised CMEA firms performed significantly better than non-privatised firms did over the transition period. However, examining the interaction effect of ownership with EU trade orientation, we observe that the benefits of privatisation are not present in the sample of EU oriented firms. There are no advantages to privatisation in historically EU trade oriented firms. The above results may be a result of the selection processes modelled in Table 8 since both historical firm performance and trade orientation played a role in the determination of firm structure in 1996. Thus, in our final specification we instrument the ownership variable in order to correct for such sample selection problems. The final column of Table 9 documents the results of the growth models using the predicted values of ownership from Table 8. Our results are robust to such instrumentation. Firms that are EU trade oriented perform significantly 
better over the transition period than those firms producing products that were previously directed to the CMEA, but there are no benefits to the privatisation of such, while CMEA firms reap benefits from privatisation. These results hold even when conditioned on the fact that all EU firms were less likely to be privatised, while good firms from a CMEA background were more likely to privatised.

From the above, it is clear that the average effects of private ownership had a positive effect on performance during the entire transition period amongst firms coming from a background of producing a product for the CMEA market, even when we control for possible endogeneity in the ownership structure. We now decompose the average effect into its two main components: that determined by privatisation to insiders and that due to outsider privatisation. The results are documented in Table 10. Once again, country, regional, product and year controls are highly significant, although not reported here. In columns 1 and 2 the benefit of outside ownership is significant even when we do not condition the effect of ownership on firm performance on inherited trade orientation.

Conditioning ownership on inherited trade orientation in column 3, we find that firms which are EU trade oriented perform significantly better than those firms producing products that were previously directed to the CMEA. Outsider ownership is positive and significant at the 5 per cent level, but only in the subsample of CMEA oriented firms. Once again, the benefits of outsider ownership are completely offset in the sample of EU oriented firms. This contrasts greatly with the effects of insider privatisation on firm performance. Insider controlled firms do not perform statistically better than majority state owned firms, irrespective of their inherited trade orientation. To correct for any possible endogeneity in ownership structure, the final column uses the predicted values of ownership from Table 8 . The results are duplicated even when using instrumented ownership.

\section{Conclusions}

In this paper we use representative survey data, a rich unbalanced panel of 220 traditional manufacturing firms over 7 years and 4 CEE countries with detailed information on employment, ownership, regional and product classification, to model the determinants of firm performance and ownership structures during transition. We highlight the role of historical firm trade orientation, whether producing for the EU or CMEA market under planning, on the determination of firm performance during 
transition and the political constraints it imposes on the determination of ownership structure and its subsequent impact on firm performance, among other factors.

Controlling for other factors, firms that produce historically EU oriented products consistently outperform firms that inherited products historically produced for the CMEA market during the first 7 years of transition across our 4 CEE countries. We provide evidence that while CEE countries where eager to restructure the best firms in historically CMEA markets under outsider ownership, they resisted outsider ownership in historically EU markets. In historically CMEA markets, outsiders were given the best firms to restructure during transition, while the state and insiders maintained control of the loss making and politically sensitive firms across our CEE countries during the first 7 years of transition. This was done to build political support for the restructuring of previously CMEA market. The more problematic loss making firms would be dealt with later.

The political economy of privatising EU trade oriented state firms was more in line with those observed in western economies. We show that the state and insiders in such firms were reluctant to privatise these highly viable and expanding firms to outsiders. Politically, it was more beneficial to retain control, undertake restructuring, and support reforms that developed a properly functioning stock exchange, which would eventually allow a successful public offering to outsiders. This was done to build political support from populations linked to the previously EU market. The more problematic issue of selling valuable assets to outsiders, for efficiency reasons, would naturally happen at a later date.

As a result of the different political constraints imposed on the selection process to outside ownership, the effect of corporate governance on firm performance was shown to be different among previously CMEA and EU trade oriented firms. Majority outside ownership outperforms majority insider/state ownership, but only when we condition our regression on initial CMEA trade orientation controlling for a gradualist selection process, pre- and post- privatisation effects, amongst other factors. This results from the political incentives to preserve loss-making firms in the short-run. Majority outside ownership does not outperform majority state/insider ownership when conditioned on initial EU trade orientation. This result is not surprising given the political resistance to giving the best EU oriented firms to outsiders and the fact that such firms are subcontracted by foreign licence, face upstream competition in their EU 
market, do not have liquidity constraints and inherited mangers with experience in global markets.

It is our thesis that political economy considerations induced insider profit maximising considerations in historically EU oriented firms and insider cost minimising considerations in historically CMEA oriented firms to have an important impact on the privatisation process and its subsequent impact on firm performance. Throughout this paper we have provided empirical evidence that political constraints driven by market demand considerations, rather than political distortions, have imposed themselves on the privatisation process and its subsequent impact on firm performance in Central Eastern Europe. Employment gains from privatisation are evident in historically CMEA oriented firms. Similar gains from privatisation are not present in historically EU oriented firms, but their inheritance ensured that such firms performed relatively well in terms of employment creation during transition and irrespective of whether they were privatised or not. Clearly trade liberalisation and history rather than privatisation induced these employment gains.

The conditioning of our analysis on initial demand conditions greatly helps to unravel puzzling empirical outcomes in relation to issues of corporate governance in CEE. The established literature sees insider privatisation as a political distortion that blocks efficiency gains from the privatisation programme during transition. Yet if one conditions firm performance and the sequencing process to outside privatisation on initial trade orientation, among other factors, one gets an accurate description of the role of insider ownership in the countries of CEE. Insider ownership is an important political outcome, driven by market demand considerations, that builds up political support for market reforms during its initial stages, ensuring their long-term success. 
Table 1: 1988 Trade Orientation of Manufacturing Products

\begin{tabular}{|c|c|c|c|c|c|}
\hline 1-Digit Sector & $\begin{array}{c}\text { Clio3 } \\
\text { Products }\end{array}$ & $\begin{array}{l}\text { Bulgaria } \\
\text { EU Trade }\end{array}$ & $\begin{array}{l}\text { Hungary } \\
\text { EU Trade }\end{array}$ & $\begin{array}{l}\text { Slovakia } \\
\text { EU Trade }\end{array}$ & $\begin{array}{l}\text { Slovenia } \\
\text { EU Trade }\end{array}$ \\
\hline 1. Food, Beverage and Tobacco & $\begin{array}{l}411 \\
412 \\
413 \\
414 \\
415 \\
416 \\
417 \\
418 \\
419 \\
420 \\
421 \\
422 \\
423 \\
424 \\
425 \\
426 \\
427 \\
428 \\
429 \\
\end{array}$ & $\begin{array}{l}0 \\
1 \\
1 \\
1 \\
1 \\
0 \\
0 \\
0 \\
0 \\
0 \\
0 \\
1 \\
0 \\
0 \\
0 \\
0 \\
0 \\
0 \\
0 \\
\end{array}$ & $\begin{array}{l}0 \\
1 \\
1 \\
1 \\
0 \\
0 \\
0 \\
0 \\
0 \\
0 \\
0 \\
1 \\
1 \\
0 \\
0 \\
0 \\
0 \\
0 \\
0 \\
\end{array}$ & $\begin{array}{l}0 \\
1 \\
1 \\
1 \\
0 \\
0 \\
0 \\
0 \\
0 \\
0 \\
1 \\
0 \\
1 \\
0 \\
0 \\
0 \\
1 \\
0 \\
0 \\
\end{array}$ & $\begin{array}{l}1 \\
1 \\
0 \\
1 \\
0 \\
0 \\
0 \\
0 \\
0 \\
1 \\
1 \\
1 \\
1 \\
0 \\
0 \\
0 \\
0 \\
0 \\
0 \\
\end{array}$ \\
\hline 2. Textiles and Textile Products & $\begin{array}{l}431 \\
432 \\
436 \\
438 \\
439 \\
453 \\
455 \\
456\end{array}$ & $\begin{array}{l}1 \\
1 \\
1 \\
1 \\
0 \\
1 \\
1 \\
0\end{array}$ & $\begin{array}{l}1 \\
1 \\
1 \\
1 \\
0 \\
1 \\
1 \\
1\end{array}$ & $\begin{array}{l}0 \\
1 \\
1 \\
1 \\
1 \\
1 \\
1 \\
0\end{array}$ & $\begin{array}{l}1 \\
1 \\
1 \\
0 \\
0 \\
1 \\
1 \\
0\end{array}$ \\
\hline 3. Leather and Leather Products & $\begin{array}{l}441 \\
442 \\
451 \\
\end{array}$ & $\begin{array}{l}0 \\
1 \\
1 \\
\end{array}$ & $\begin{array}{l}1 \\
1 \\
1 \\
\end{array}$ & $\begin{array}{l}0 \\
1 \\
1 \\
\end{array}$ & $\begin{array}{l}1 \\
0 \\
1 \\
\end{array}$ \\
\hline 4. Wood Products & $\begin{array}{l}461 \\
462 \\
463 \\
464 \\
465 \\
466 \\
467\end{array}$ & $\begin{array}{l}1 \\
1 \\
0 \\
0 \\
1 \\
1 \\
1\end{array}$ & $\begin{array}{l}1 \\
1 \\
1 \\
0 \\
1 \\
0 \\
1\end{array}$ & $\begin{array}{l}1 \\
1 \\
0 \\
0 \\
0 \\
0 \\
1\end{array}$ & $\begin{array}{l}1 \\
1 \\
1 \\
0 \\
0 \\
1 \\
1\end{array}$ \\
\hline 5. Paper, Printing and Publishing & $\begin{array}{l}471 \\
472 \\
473 \\
474\end{array}$ & $\begin{array}{l}1 \\
0 \\
1 \\
0\end{array}$ & $\begin{array}{l}1 \\
0 \\
1 \\
0\end{array}$ & $\begin{array}{l}1 \\
0 \\
1 \\
0\end{array}$ & $\begin{array}{l}1 \\
1 \\
0 \\
0\end{array}$ \\
\hline 6. Fuels Production & $\begin{array}{l}120 \\
140 \\
152\end{array}$ & $\begin{array}{l}0 \\
1 \\
0\end{array}$ & $\begin{array}{l}0 \\
1 \\
0\end{array}$ & $\begin{array}{l}0 \\
1 \\
0\end{array}$ & $\begin{array}{l}0 \\
1 \\
0\end{array}$ \\
\hline 7. Chemicals, products, fibers & $\begin{array}{l}252 \\
253 \\
255 \\
256 \\
257 \\
258 \\
259 \\
260\end{array}$ & $\begin{array}{l}1 \\
1 \\
0 \\
1 \\
1 \\
0 \\
0 \\
0\end{array}$ & $\begin{array}{l}1 \\
1 \\
0 \\
1 \\
0 \\
0 \\
0 \\
1\end{array}$ & $\begin{array}{l}1 \\
1 \\
0 \\
1 \\
0 \\
0 \\
0 \\
1\end{array}$ & $\begin{array}{l}1 \\
1 \\
0 \\
1 \\
0 \\
0 \\
1 \\
1\end{array}$ \\
\hline 8. Rubber and Plastic Products & $\begin{array}{l}481 \\
482 \\
483\end{array}$ & $\begin{array}{l}1 \\
0 \\
1\end{array}$ & $\begin{array}{l}1 \\
0 \\
1\end{array}$ & $\begin{array}{l}1 \\
0 \\
1\end{array}$ & $\begin{array}{l}1 \\
0 \\
0\end{array}$ \\
\hline
\end{tabular}


William Davidson Institute Working Paper 338

\begin{tabular}{|c|c|c|c|c|c|}
\hline 1-Digit Sector & $\begin{array}{r}\text { Clio3 } \\
\text { Products }\end{array}$ & $\begin{array}{l}\text { Bulgaria } \\
\text { EU Trade }\end{array}$ & $\begin{array}{l}\text { Hungary } \\
\text { EU Trade }\end{array}$ & $\begin{array}{l}\text { Slovakia } \\
\text { EU Trade }\end{array}$ & $\begin{array}{l}\text { Slovenia } \\
\text { EU Trade }\end{array}$ \\
\hline 9. Mineral Materials and Products & $\begin{array}{l}241 \\
242 \\
243 \\
245 \\
246 \\
247 \\
248 \\
\end{array}$ & $\begin{array}{l}1 \\
0 \\
0 \\
1 \\
0 \\
1 \\
1\end{array}$ & $\begin{array}{l}0 \\
1 \\
0 \\
1 \\
0 \\
1 \\
1\end{array}$ & $\begin{array}{l}0 \\
1 \\
1 \\
0 \\
0 \\
1 \\
1\end{array}$ & $\begin{array}{l}0 \\
1 \\
0 \\
1 \\
1 \\
1 \\
1\end{array}$ \\
\hline 10. Basic Metals and Fab. products & $\begin{array}{l}221 \\
222 \\
223 \\
224 \\
311 \\
312 \\
313 \\
314 \\
315 \\
316\end{array}$ & $\begin{array}{l}1 \\
1 \\
1 \\
1 \\
0 \\
0 \\
0 \\
0 \\
0 \\
1\end{array}$ & $\begin{array}{l}1 \\
1 \\
1 \\
1 \\
1 \\
0 \\
0 \\
1 \\
0 \\
1\end{array}$ & $\begin{array}{l}1 \\
1 \\
1 \\
1 \\
0 \\
0 \\
1 \\
1 \\
0 \\
1\end{array}$ & $\begin{array}{l}1 \\
1 \\
1 \\
1 \\
1 \\
0 \\
0 \\
1 \\
0 \\
1\end{array}$ \\
\hline 11. Machinery, excluding Electrical & $\begin{array}{l}321 \\
322 \\
323 \\
324 \\
325 \\
326 \\
327 \\
328\end{array}$ & $\begin{array}{l}0 \\
1 \\
0 \\
0 \\
1 \\
1 \\
0 \\
1\end{array}$ & $\begin{array}{l}1 \\
1 \\
0 \\
1 \\
1 \\
1 \\
1 \\
1\end{array}$ & $\begin{array}{l}1 \\
1 \\
1 \\
0 \\
1 \\
1 \\
0 \\
1\end{array}$ & $\begin{array}{l}1 \\
1 \\
0 \\
1 \\
1 \\
1 \\
1 \\
1\end{array}$ \\
\hline 12. Electrical and Optical Equipment & $\begin{array}{l}330 \\
341 \\
342 \\
343 \\
344 \\
345 \\
346 \\
347 \\
371 \\
372 \\
373 \\
374 \\
\end{array}$ & $\begin{array}{l}1 \\
0 \\
1 \\
1 \\
1 \\
1 \\
1 \\
1 \\
1 \\
1 \\
0 \\
0 \\
\end{array}$ & $\begin{array}{l}0 \\
0 \\
1 \\
1 \\
1 \\
1 \\
1 \\
1 \\
1 \\
1 \\
0 \\
0\end{array}$ & $\begin{array}{l}1 \\
1 \\
1 \\
1 \\
1 \\
1 \\
1 \\
1 \\
1 \\
0 \\
0 \\
1\end{array}$ & $\begin{array}{l}1 \\
1 \\
1 \\
1 \\
1 \\
1 \\
1 \\
0 \\
1 \\
0 \\
1 \\
0\end{array}$ \\
\hline 13. Transport Equipment & $\begin{array}{l}351 \\
352 \\
353 \\
361 \\
362 \\
363 \\
364 \\
365\end{array}$ & $\begin{array}{l}0 \\
0 \\
1 \\
0 \\
1 \\
0 \\
0 \\
0\end{array}$ & $\begin{array}{l}1 \\
0 \\
1 \\
0 \\
1 \\
0 \\
1 \\
0\end{array}$ & $\begin{array}{l}1 \\
0 \\
1 \\
0 \\
1 \\
1 \\
0 \\
0\end{array}$ & $\begin{array}{l}1 \\
1 \\
1 \\
0 \\
0 \\
1 \\
1 \\
0\end{array}$ \\
\hline 14. Other Manufactured Products & $\begin{array}{l}491 \\
492 \\
494 \\
495\end{array}$ & $\begin{array}{l}0 \\
0 \\
1 \\
1\end{array}$ & $\begin{array}{l}1 \\
0 \\
0 \\
1\end{array}$ & $\begin{array}{l}1 \\
0 \\
1 \\
1\end{array}$ & $\begin{array}{l}0 \\
0 \\
1 \\
1\end{array}$ \\
\hline
\end{tabular}


Table 2a: Share of EU Oriented Clio3 Products within Sectors in 1988

\begin{tabular}{|l|c|c|c|c|c|}
\hline \multicolumn{1}{|c|}{ Nace Rev 1 Digit Sector } & \# Products per & \multicolumn{3}{|c|}{ Share of EU Trade Oriented Products } \\
\cline { 3 - 6 } & Sector & Bulgaria & Hungary & Slovakia & Slovenia \\
\hline 1. Food, Beverage and Tobacco & 19 & 0.26 & 0.26 & 0.32 & 0.37 \\
2. Textiles and Textile Products & 8 & 0.75 & 0.88 & 0.75 & 0.63 \\
3. Leather and Leather Products & 3 & 0.67 & 1.00 & 0.67 & 0.67 \\
4. Wood Products & 7 & 0.71 & 0.71 & 0.43 & 0.71 \\
5. Paper, Printing and Publishing & 4 & 0.50 & 0.50 & 0.50 & 0.50 \\
6. Fuels Production & 3 & 0.33 & 0.33 & 0.33 & 0.33 \\
7. Chemicals Products, Fibres & 8 & 0.50 & 0.50 & 0.50 & 0.63 \\
8. Rubber and Plastic Products & 3 & 0.67 & 0.67 & 0.67 & 0.33 \\
9. Mineral Materials and Products & 7 & 0.57 & 0.57 & 0.57 & 0.71 \\
10. Basic Metals and Fabricated Products & 10 & 0.50 & 0.70 & 0.70 & 0.70 \\
11. Machinery, excluding Electrical & 8 & 0.50 & 0.88 & 0.75 & 0.88 \\
12. Electrical and Optical Equipment & 12 & 0.75 & 0.67 & 0.83 & 0.75 \\
13. Transport Equipment & 8 & 0.25 & 0.50 & 0.50 & 0.63 \\
\hline
\end{tabular}

Table 2b: Annual Average Growth in Sector Exports, 1988-96

\begin{tabular}{|l|c|c|c|c|}
\hline Nace Rev 1 Digit Sector & Bulgaria & Hungary & Slovakia & Slovenia \\
\hline 1. Food, Beverage and Tobacco & 0.09 & 0.07 & 0.16 & 0.11 \\
2. Textiles and Textile Products & 0.28 & 0.24 & 0.31 & 0.21 \\
3. Leather and Leather Products & 0.37 & 0.32 & 0.38 & 0.14 \\
4. Wood Products & 0.17 & 0.14 & 0.21 & 0.15 \\
5. Paper, Printing and Publishing & 0.06 & 0.19 & 0.19 & 0.15 \\
6. Fuels Production & 0.09 & 0.15 & 0.18 & 0.63 \\
7. Chemicals Products, Fibres & 0.17 & 0.12 & 0.26 & 0.22 \\
8. Rubber and Plastic Products & 0.15 & 0.19 & 0.29 & 0.19 \\
9. Mineral Materials and Products & 0.21 & 0.14 & 0.22 & 0.21 \\
10. Basic Metals and Fabricated Products & 0.23 & 0.16 & 0.31 & 0.20 \\
11. Machinery, excluding Electrical & 0.15 & 0.23 & 0.29 & 0.27 \\
12. Electrical and Optical Equipment & 0.16 & 0.35 & 0.41 & 0.21 \\
13. Transport Equipment & 0.29 & 0.58 & 0.59 & 0.22 \\
\hline
\end{tabular}

Table 2c: 1988 Trade Oriented Products: Exports in 1996 as a Share of 1996 Exports

\begin{tabular}{|l|c|c|c|c|}
\hline Nace Rev 1 Digit Sector & Bulgaria & Hungary & Slovakia & Slovenia \\
\hline 1. Food, Beverage and Tobacco & 1.0 & 0.9 & 0.6 & 0.8 \\
2. Textiles and Textile Products & 1.0 & 1.0 & 1.0 & 1.0 \\
3. Leather and Leather Products & 0.9 & 1.0 & 0.9 & 0.9 \\
4. Wood Products & 1.0 & 1.0 & 0.8 & 0.9 \\
5. Paper, Printing and Publishing & 0.8 & 0.7 & 0.8 & 0.9 \\
6. Fuels Production & 1.0 & 1.0 & 1.0 & 1.0 \\
7. Chemicals Products, Fibres & 1.0 & 0.9 & 1.0 & 0.9 \\
8. Rubber and Plastic Products & 1.0 & 1.0 & 1.0 & 0.6 \\
9. Mineral Materials and Products & 0.9 & 0.9 & 1.0 & 0.9 \\
10. Basic Metals and Fabricated Products & 1.0 & 1.0 & 0.9 & 0.9 \\
11. Machinery, excluding Electrical & 0.9 & 1.0 & 0.9 & 1.0 \\
12. Electrical and Optical Equipment & 0.8 & 0.7 & 1.0 & 1.0 \\
13. Transport Equipment & 0.2 & 1.0 & 1.0 & 1.0 \\
\hline
\end{tabular}

Source: EUROSTAT Trade Data, 1988 
Table 3: Evolution of Manufacturing Employment

\begin{tabular}{|l|c|c|c|c|c|c|}
\hline & $\mathbf{1 9 9 1}$ & $\mathbf{1 9 9 2}$ & $\mathbf{1 9 9 3}$ & $\mathbf{1 9 9 4}$ & $\mathbf{1 9 9 5}$ & $\mathbf{1 9 9 6}$ \\
\hline Bulgaria & & & & & & \\
Actual & 1 & 0.83 & 0.70 & 0.67 & 0.75 & 0.79 \\
Survey - All & 1 & 0.84 & 0.74 & 0.69 & 0.76 & 0.74 \\
Survey - CMEA & 1 & 0.83 & 0.68 & 0.62 & 0.67 & 0.65 \\
Survey - EU & 1 & 0.84 & 0.76 & 0.71 & 0.79 & 0.78 \\
Hungary & & & & & & \\
Actual & 1 & 0.85 & 0.74 & 0.68 & 0.65 & 0.63 \\
Survey-All & 1 & 0.94 & 0.86 & 0.79 & 0.75 & 0.71 \\
Survey-CMEA & 1 & 0.94 & 0.86 & 0.78 & 0.72 & 0.63 \\
Survey - EU & 1 & 0.95 & 0.87 & 0.80 & 0.77 & 0.76 \\
Slovakia & & & & & & \\
Actual & 1 & 0.87 & 0.78 & 0.75 & 0.75 & 0.74 \\
Survey - All & 1 & 0.98 & 0.93 & 0.87 & 0.86 & 0.85 \\
Survey-CMEA & 1 & 0.99 & 0.96 & 0.82 & 0.82 & 0.81 \\
Survey-EU & 1 & 0.97 & 0.92 & 0.88 & 0.87 & 0.86 \\
Slovenia & & & & & & \\
Actual & 1 & 0.89 & 0.81 & 0.77 & 0.74 & 0.69 \\
Survey-All & 1 & 0.95 & 0.90 & 0.91 & 0.89 & 0.86 \\
Survey-CMEA & 1 & 0.91 & 0.78 & 0.73 & 0.71 & 0.63 \\
Survey-EU & 1 & 0.95 & 0.92 & 0.95 & 0.92 & 0.90 \\
\hline
\end{tabular}

Source: LICOS Industrial Database and LICOS Survey Database

Table 4: Number of Firms by Sector and Trade Orientation

\begin{tabular}{|c|c|c|c|c|c|c|c|c|c|c|c|c|}
\hline \multirow[t]{2}{*}{ Nace Rev 1 Digit Sector } & \multicolumn{3}{|c|}{ Bulgaria } & \multicolumn{3}{|c|}{ Hungary } & \multicolumn{3}{|c|}{ Slovakia } & \multicolumn{3}{|c|}{ Slovenia } \\
\hline & $\underset{\#}{\#}$ & ๑ & $\sum_{U}^{\ll}$ & $\underbrace{\mathscr{E}}_{\#}$ & P्工 & 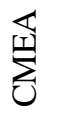 & $\underbrace{\stackrel{\Xi}{\Xi}}_{\#}$ & ? & $\sum_{U}^{\mathbb{I}}$ & $\underset{\#}{\text { E }}$ & 只 & $\sum_{\circlearrowright}^{\overleftarrow{U}}$ \\
\hline 1. Food, Beverage and Tobacco & 18 & 7 & 11 & 26 & 12 & 14 & 1 & 1 & 0 & 7 & 2 & 5 \\
\hline 2. Textiles and Textile Products & 13 & 12 & 1 & 11 & 10 & 1 & 12 & 10 & 2 & 5 & 5 & 0 \\
\hline 3. Leather and Leather Products & 3 & 2 & 1 & 1 & 1 & 0 & 0 & 0 & 0 & 2 & 2 & 0 \\
\hline 4. Wood Products & 9 & 8 & 1 & 2 & 2 & 0 & 3 & 2 & 1 & 5 & 5 & 0 \\
\hline 5. Paper, Printing and Publishing & 2 & 0 & 2 & 1 & 1 & 0 & 0 & 0 & 0 & 3 & 2 & 1 \\
\hline 6. Fuels Production & 0 & 0 & 0 & 0 & 0 & 0 & 1 & 1 & 0 & 1 & 1 & 0 \\
\hline 7. Chemicals Products, Fibres & 2 & 1 & 1 & 5 & 1 & 4 & 8 & 4 & 4 & 1 & 0 & 1 \\
\hline 8. Rubber and Plastic Products & 3 & 3 & 0 & 2 & 2 & 0 & 2 & 2 & 0 & 0 & 0 & 0 \\
\hline 9. Mineral Materials and Products & 2 & 0 & 2 & 1 & 1 & 0 & 3 & 3 & 0 & 2 & 2 & 0 \\
\hline 10. Basic Metals and Fabricated Products & 2 & 1 & 1 & 7 & 2 & 5 & 7 & 7 & 0 & 4 & 2 & 2 \\
\hline 11. Machinery, excluding Electrical & 8 & 5 & 3 & 3 & 3 & 0 & 3 & 3 & 0 & 2 & 2 & 0 \\
\hline 12. Electrical and Optical Equipment & 2 & 2 & 0 & 6 & 6 & 0 & 6 & 5 & 1 & 3 & 3 & 0 \\
\hline 13. Transport Equipment & 3 & 2 & 1 & 1 & 1 & 0 & 2 & 1 & 1 & 2 & 2 & 0 \\
\hline 14. Other Manufactured Products & 1 & 1 & 0 & 1 & 1 & 0 & 0 & 0 & 0 & 0 & 0 & 0 \\
\hline TOTAL & 68 & 44 & 24 & 67 & 43 & 24 & 48 & 39 & 9 & 37 & 28 & 9 \\
\hline $\begin{array}{l}\text { Total Firms Overall = } 220 \\
\text { Total EU Firms Overall = } 154\end{array}$ & & & & & & & & & & & & \\
\hline
\end{tabular}


Table 5: Manufacturing Firms by Regional Classifications According to the Nomenclature of Territorial Units for Statistics (NUTS) ${ }^{1}$

\begin{tabular}{|c|c|c|c|c|c|}
\hline Bulgaria & EU & CMEA & Hungary & EU & CMEA \\
\hline Sofia - Capital City & 5 & 3 & Budapest & 13 & 7 \\
\hline Dobrich & 3 & 2 & Pest & 5 & 1 \\
\hline Veliko Turnovo & 1 & 1 & Veszprem & 1 & 1 \\
\hline Gabrovo & 3 & 0 & Komaron-Esztergom & 1 & 1 \\
\hline Lovech & 2 & 1 & Gyor-Moson-Sopron & 1 & 2 \\
\hline Pleven & 2 & 0 & Zala & 3 & 1 \\
\hline Vidin & 2 & 1 & Baranya & 2 & 0 \\
\hline Vratsa & 1 & 0 & Somogy & 0 & 3 \\
\hline Razgrad & 2 & 3 & Tolna & 1 & 0 \\
\hline Rousse & 1 & 1 & Borsod-Abauj-Zempln & 1 & 2 \\
\hline Silistra & 1 & 2 & Heves & 1 & 0 \\
\hline Turgovishte & 3 & 1 & Nograd & 3 & 0 \\
\hline Bourgas & 2 & 0 & Hajdu-Bihar & 1 & 1 \\
\hline Sliven & 1 & 1 & Jasz-Nagykun-Szolnok & 2 & 0 \\
\hline Yambol & 2 & 1 & Szabolcs-Szatmar-Bereg & 2 & 2 \\
\hline Pazardjik & 1 & 1 & Bacs-Kiskun & 1 & 0 \\
\hline Plovdiv & 2 & 3 & Bekes & 2 & 2 \\
\hline Blagoevgrad & 1 & 0 & Csongrad & 3 & 1 \\
\hline Pernik & 2 & 1 & & & \\
\hline Kurdjali & 3 & 1 & & & \\
\hline Stara Zagora & 1 & 1 & & & \\
\hline Haskovo & 3 & 0 & & & \\
\hline Total Firms & 44 & 24 & Total Firms & 43 & 24 \\
\hline Slovakia & EU & CMEA & Slovenia & EU & CMEA \\
\hline Bratislavsky & 5 & 0 & Pomurska & 4 & 4 \\
\hline Trnavsky & 2 & 1 & Podravska & 4 & 2 \\
\hline Trenciansky & 5 & 4 & Koroska & 2 & 0 \\
\hline Nitriansky & 4 & 1 & Savinjska & 4 & 1 \\
\hline Zilinsky & 5 & 0 & Dolenjska & 3 & 0 \\
\hline Banskobystricky & 8 & 0 & Osrednjeslovenska & 2 & 0 \\
\hline Presovsky & 4 & 3 & Gorenjska & 6 & 1 \\
\hline Kosicky & 6 & 0 & Notranjsko-Kraska & 2 & 0 \\
\hline & & & Oblano-Kraska & 1 & 1 \\
\hline Total Firms & 39 & 9 & Total Firms & 28 & 9 \\
\hline
\end{tabular}

${ }^{1 .}$ Regional Classification Level-3 NUTS Source: LICOS Survey Database

Table 6: Ownership Structure of Survey Sample

\begin{tabular}{|c|c|c|c|}
\hline & Total Sample & $\begin{array}{c}\text { EU Trade Oriented } \\
\text { Firms }\end{array}$ & $\begin{array}{c}\text { CMEA Oriented } \\
\text { Firms }\end{array}$ \\
\hline Total Number of Firms & $\mathbf{2 2 0}$ & $\mathbf{1 5 4}$ & $\mathbf{6 6}$ \\
Majority State Owned & $35 \%$ & $34 \%$ & $38 \%$ \\
Majority Outsider Owned & $40 \%$ & $39 \%$ & $21 \%$ \\
Majority Insider Owned & $25 \%$ & $27 \%$ & \\
\hline
\end{tabular}

Source: LICOS Survey Database 
Table 7: Survey Manufacturing Employment Growth and Size

\begin{tabular}{|l|c|c|c|c|}
\hline & Size 1990-92 & Size 1992-96 & $\begin{array}{c}\text { Growth } \\
\mathbf{1 9 9 0 - 9 2}\end{array}$ & $\begin{array}{c}\text { Growth } \\
\mathbf{1 9 9 2 - 9 6}\end{array}$ \\
\hline Majority State Owned & & & & \\
EU Firms & 1045 & 833 & -0.09 & -0.02 \\
CMEA Firms & 652 & 622 & -0.12 & -0.07 \\
\hline Majority Privatised & & & & \\
EU Firms & 987 & 801 & -0.05 & -0.03 \\
CMEA Firms & 949 & 648 & -0.03 & -0.06 \\
$\quad$ Majority Outsider Owned & & & & -0.03 \\
$\quad$ EU Firms & 1252 & 967 & -0.05 & -0.04 \\
$\quad$ CMEA Firms & 1260 & 856 & -0.02 & -0.01 \\
$\quad$ Majority Insider Owned & & & & -0.06 \\
EU Firms & 685 & 594 & -0.03 & -0.11 \\
$\quad$ CMEA Firms & 395 & 320 & & \\
& & & & \\
\hline
\end{tabular}

Source: LICOS Survey Database

Table 8: Ownership Selection Logit Regressions: State and Privatised Manufacturing Firms $1996^{\mathrm{a}}$

\begin{tabular}{|c|c|c|c|}
\hline \multirow[b]{2}{*}{ Ownership $_{96}$} & \multirow{2}{*}{$\begin{array}{l}\text { Model I Logit: } \\
\text { State vs. Private }\end{array}$} & \multicolumn{2}{|c|}{ Model II Multinomial Logit: } \\
\hline & & $\begin{array}{l}\text { State vs. } \\
\text { Outsiders }\end{array}$ & $\begin{array}{l}\text { State vs. } \\
\text { Insiders }\end{array}$ \\
\hline Growth $_{t-4}$ & $\begin{array}{c}34.6 \\
(2.82)^{*} \\
\end{array}$ & $\begin{array}{c}46.6 \\
(3.00)^{*} \\
\end{array}$ & $\begin{array}{c}33.0 \\
(2.07)^{*} \\
\end{array}$ \\
\hline Trade Orientation & $\begin{array}{c}-3.98 \\
(2.63)^{*}\end{array}$ & $\begin{array}{c}-3.97 \\
(2.35)^{*}\end{array}$ & $\begin{array}{l}-2.99 \\
(1.68) \\
\end{array}$ \\
\hline $\begin{array}{l}\text { Growth }_{\mathrm{t}-4} \mathrm{X} \\
\text { Trade Orientation }\end{array}$ & $\begin{array}{c}-35.4 \\
(2.77)^{*}\end{array}$ & $\begin{array}{c}-51.0 \\
(3.05)^{*}\end{array}$ & $\begin{array}{l}-15.8 \\
(0.94) \\
\end{array}$ \\
\hline Constant & $\begin{array}{c}2.51 \\
(1.36)\end{array}$ & $\begin{array}{c}0.86 \\
(0.50)\end{array}$ & $\begin{array}{l}-72.4 \\
(0.00)\end{array}$ \\
\hline Regional Level Dummies & YES & YES & YES \\
\hline Sector Dummies & YES & YES & YES \\
\hline Country Dummies & YES & YES & YES \\
\hline $\mathbf{R}^{2}$ & 0.63 & \multicolumn{2}{|c|}{0.70} \\
\hline Number Observations & 176 & \multicolumn{2}{|c|}{176} \\
\hline
\end{tabular}

${ }^{\mathrm{a}} \mathrm{T}$-statistics in parentheses

* Significant at the 5 per cent level 
Table 9: Ownership Regressions: State and Privatised Manufacturing Firms over the period 1991-1996 ${ }^{\mathrm{a}}$

\begin{tabular}{|l|c|c|c|c|}
\hline & \multicolumn{3}{|c|}{ State versus Private Ownership } & $\begin{array}{c}\text { Instrumented } \\
\text { Ownership }\end{array}$ \\
\hline Growth Firm t & Model I & Model II & Model III & Model IV \\
\hline Initial Size & -0.00001 & -0.00001 & -0.00003 & -0.00002 \\
& $(1.50)$ & $(1.80)$ & $(1.56)$ & $(0.74)$ \\
\hline Initial Size X & & & 0.00002 & 0.00002 \\
Trade Orientation & & & $(0.98)$ & $(0.62)$ \\
\hline Privatised Ownership & 0.04 & 0.04 & 0.14 & 0.22 \\
& $(1.70)$ & $(1.75)$ & $(3.00)^{*}$ & $(2.82)^{*}$ \\
\hline Trade Orientation & & 0.10 & 0.16 & 0.22 \\
& & $(1.67)$ & $(1.98)^{*}$ & $(2.00)^{*}$ \\
\hline Privatised Ownership X & & & -0.12 & -0.17 \\
Trade Orientation & & & $(2.36)^{*}$ & $(2.08)^{*}$ \\
\hline Constant & -0.16 & -0.27 & -0.29 & -0.47 \\
& $(1.80)$ & $(2.44)^{*}$ & $(2.61)^{*}$ & $(3.31)^{*}$ \\
\hline Country Dummies & YES & YES & YES & YES \\
\hline Regional Level Dummies: NUTS level 3 & YES & YES & YES & YES \\
\hline Product Dummies: NACE CLIO 3 & YES & YES & YES & YES \\
\hline Year Dummies & YES & YES & YES & YES \\
\hline$R^{2}$ & 0.28 & 0.28 & 0.29 & 0.28 \\
\hline Number Observations & 1003 & 1003 & 1003 & 938 \\
\hline Heteroscedasticity & $\chi 2(137)=146$ & $\chi 2(136)=121$ & $\chi 2(136)=126$ & $\chi 2(128)=110$ \\
\hline Autocorrelation, AR1 & $\chi 2(1)=8$ & $\chi 2(1)=8$ & $\chi 2(1)=10$ & $\chi 2(1)=9$ \\
\hline & & & & \\
\hline
\end{tabular}

a T-statistics in parentheses

* Significant at the 5 per cent level 
Table 10: Ownership Regressions: Majority State, Outside and Insider Owned Manufacturing Firms over the period 1991-1996 ${ }^{\mathrm{a}}$

\begin{tabular}{|c|c|c|c|c|}
\hline \multirow[b]{2}{*}{ Growth Firm $_{t}$} & \multicolumn{3}{|c|}{ State versus Inside and Outside Ownership } & \multirow{2}{*}{$\begin{array}{c}\begin{array}{c}\text { Instrumented } \\
\text { Ownership }\end{array} \\
\text { Model IV } \\
\end{array}$} \\
\hline & Model I & Model II & Model III & \\
\hline Initial Size & $\begin{array}{c}-0.00001 \\
(1.47)\end{array}$ & $\begin{array}{c}-0.00002 \\
(1.94)\end{array}$ & $\begin{array}{c}-0.00003 \\
(1.52)\end{array}$ & $\begin{array}{c}-0.00002 \\
(0.91)\end{array}$ \\
\hline $\begin{array}{l}\text { Initial Size X } \\
\text { Trade Orientation }\end{array}$ & & & $\begin{array}{c}0.00002 \\
(0.88)\end{array}$ & $\begin{array}{c}0.00002 \\
(0.75)\end{array}$ \\
\hline Insider Owned & $\begin{array}{l}0.004 \\
(0.13) \\
\end{array}$ & $\begin{array}{l}-0.01 \\
(0.42) \\
\end{array}$ & $\begin{array}{c}0.08 \\
(1.19) \\
\end{array}$ & $\begin{array}{c}0.05 \\
(0.44) \\
\end{array}$ \\
\hline Outsider Owned & $\begin{array}{c}0.05 \\
(2.10)^{*}\end{array}$ & $\begin{array}{c}0.06 \\
(2.40)^{*} \\
\end{array}$ & $\begin{array}{c}0.14 \\
(2.97)^{*} \\
\end{array}$ & $\begin{array}{c}0.17 \\
(2.32)^{*}\end{array}$ \\
\hline Trade Orientation & & $\begin{array}{c}0.15 \\
(2.41)^{*}\end{array}$ & $\begin{array}{c}0.20 \\
(2.37)^{*}\end{array}$ & $\begin{array}{c}0.21 \\
(1.99)^{*}\end{array}$ \\
\hline $\begin{array}{l}\text { Insider Owned X } \\
\text { Trade Orientation }\end{array}$ & & & $\begin{array}{l}-0.11 \\
(1.40) \\
\end{array}$ & $\begin{array}{l}-0.07 \\
(0.68) \\
\end{array}$ \\
\hline $\begin{array}{l}\text { Outsider Owned X } \\
\text { Trade Orientation }\end{array}$ & & & $\begin{array}{c}-0.11 \\
(1.97)^{*}\end{array}$ & $\begin{array}{c}-0.18 \\
(2.23)^{*}\end{array}$ \\
\hline Constant & $\begin{array}{c}-0.18 \\
(2.01)^{*}\end{array}$ & $\begin{array}{c}-0.36 \\
(3.10)^{*}\end{array}$ & $\begin{array}{l}-0.39 \\
(3.02)^{*}\end{array}$ & $\begin{array}{l}-0.46 \\
(3.16)^{*}\end{array}$ \\
\hline Country Dummies & YES & YES & YES & YES \\
\hline Regional Level Dummies: NUTS level 3 & YES & YES & YES & YES \\
\hline Product Dummies: NACE CLIO 3 & YES & YES & YES & YES \\
\hline Year Dummies & YES & YES & YES & YES \\
\hline $\mathbf{R}^{2}$ & 0.28 & 0.29 & 0.29 & 0.27 \\
\hline Number Observations & 1003 & 1003 & 1003 & 938 \\
\hline Heteroscedasticity & $\chi 2(136)=120$ & $\chi 2(136)=121$ & $\chi 2(136)=125$ & $\chi 2(128)=108$ \\
\hline Autocorrelation, AR1 & $\chi 2(1)=8$ & $\chi 2(1)=9$ & $\chi 2(1)=10$ & $\chi 2(1)=8$ \\
\hline
\end{tabular}

a T-statistics in parentheses

* Significant at the 5 per cent level 


\section{References}

Aghion, P., O. Blanchard, and R. Burgess (1994), 'The Behaviour of State Firms in Eastern Europe, Pre-Privatisation', European Economic Review 38, pp.13271349

Alesina, A. (1987), 'Macroeconomic Policy in a Two-Party System as a Repeated Game', Quarterly Journal of Economics 102, pp.651-678

Atkeson, A. and P.J. Kehoe (1996), 'Social Insurance and Transition', International Economic Review 37, pp.377- 402

Beesley, M.E. and S.C. Littlechild (1989), 'The Regulation of Privatised Monopolies in the United Kingdom', Rand Journal of Economics 20, pp.454-473

Bennet, J. and J. Maw (1998), 'Privatisation and Market Structure in a Transition Economy', Department of Economics, University of Wales, Swansea, Mimeo

Berglof, E. and G. Roland (1998), 'Soft Budget Constraints and Banking in Transition Economies', Journal of Comparative Economics 26, pp.18-40

Bevan, A.A., S. Estrin and M.E. Schaffer (1999), 'Determinants of Enterprise Performance during Transition', Discussion Paper No.99/03, Centre for Economic Reform and Transformation, Heriot-Watt University, Edinburgh

Bilsen, V. (1997), 'The Enterprise Survey for Bulgaria, Hungary, Romania and Slovakia 1996: Questionnaire, Variables, Data Entry, Quality Control and Coding of the Answers', Leuven: LICOS Centre for Transition Economics, KU Leuven

Bishop, M.R. and J.A. Kay (1989), 'Privatisation in the United Kingdom: Lessons from Experience', World Development 17,pp.643-657

Blanchard, O. (1997), The Economics of Post-Communist Transition, Clarendon Press Oxford

Blanchard, O. and M. Kremer (1997), "Disorganization." Quarterly Journal of Economics 112, pp.1091-1126

Blanchard, O. and P. Aghion (1996), 'On Insider Privatisation', European Economic Review 40, pp.759-766

Blanchard, O., R. Dornbusch, P. Krugman, R. Layard and L. Summers (1991, Reform in Eastern Europe, MIT Press, Cambridge, MA

Bolton, P. and G. Roland, (1992), 'Privatisation in Central and Eastern Europe', Economic Policy 15, pp. 276-309

Boubakri, N. and J. Cosset (1998), 'The Financial and Operating Performance of Newly-Privatised Firms: Evidence from Developing Countries, Journal of Finance 53, pp.81-1110

Boycko, M., A. Shleifer and R.W. Vishny (1994), 'Voucher Privatisation', Journal of Financial Economics 35, pp.249-266

Boycko, M., A. Shleifer and R.W. Vishny (1996), 'A Theory of Privatisation', Economic Journal 106, pp.309-319 
Caves, R. (1990), 'Lessons from Privatisation in Britain: State Enterprise Behaviour, Public Choice and Corporate Governance', Journal of Economic Behaviour and Organisation 13, pp.145-169

Claessens, S., S. Djankov and G. Pohl, (1997), 'Ownership and Corporate Governance: Evidence from the Czech Republic', World Bank, Washington DC, Policy Research Paper No. 1737

Cornelli, F. and D.D. Li (1994), 'Large Shareholders, Private Benefits of Control and Optimal Schemes for Privatisation', LSE Financial Markets Group, Discussion Paper No. 185

Cornelli, F. and D.D. Li (1997),'Large Shareholders, Private Benefits of Control, and Optimal Schemes of Privatisations', Rand Journal of Economics 28, pp.585604

D’Souza, J., and W.L. Megginson (1998), 'The Financial and Operating Performance of Newly Privatised Firms in the 1990s', Working Paper, University of Oklahoma, Norman, OK

Davis, S. and J. Haltwinger (1992)., 'Gross Job Creation, Gross Job Destruction and Employment Reallocation', Quarterly Journal of Economics, 107, 819-863

Demougin, D. and H.W. Sinn (1994), 'Privatisation, Risk-Taking and the Communist Firm', Journal of Public Economics 55, pp.203-231

Dewatripont M. and G. Roland (1995), 'The Design of Reform Packages under Uncertainty’, American Economic Review 85, pp.1207-1223.

Dewenter, K. and P.H. Malatesta (1998), 'State-Owned and Privately-Owned Firms: An Empirical Analysis of Profitability, Leverage and Labour Intensity', Working Paper (University of Washington)

Earle, J.S. and S. Estrin (1996), 'Employee Ownership in Transition' in R. Frydman, C. Gray, and A. Rapaczynski, Eds., Corporate Governance in Central Europe and Russia, Budapest: Central European University Press

Estrin, S. (1994), Privatisation in Central and Eastern Europe, Longman

Frydman, R., C. Gray, M. Hessel and A. Rapaczynski (1999), 'When does Privatisation Work? The Impact of Private Ownership on Corporate Performance in the Transition Economies', Quarterly Journal of Economics, forthcoming

Frydman, R., K. Pistor and A. Rapaczynski (1996), 'Exit and Voice after Mass Privatisation: The Case of Russia, European Economic Review 40, pp.581-588

Hart, O., A. Shleifer and R.W. Vishny (1997), 'The Proper Scope of Government: Theory and an Application to Prisons', Quarterly Journal of Economics 112, pp.1127-1161

Hoekman, B. and S. Djankov (1997), 'Determinants of the Export Structure of Countries in Central and Eastern Europe', The World Bank Economic Review 11 , pp. $471-87$

Katz, B.G. and J. Owens (1997), 'Optimal Voucher Privatisation Fund Bids when Bidding Affects Firm Performance', Journal of Comparative Economics 24, pp. $25-43$ 
Kay, J.A. and D.J. Thompson (1986), 'Privatisation: A Policy in Search of a Rationale', Economic Journal 96, pp.18-32

Konings, J. (1997). "Firm Growth and Ownership in Transition Countries", Economics Letters, Vol. 55, pp. 413-18.

Konings, J. and P.P.Walsh (1999), 'Disorganisation in the Transition Process: FirmLevel Evidence from the Ukraine', Economics of Transition 7, pp.29-46

Kornai, J. (1988), 'Individual Freedom and Reform of the Socialist Economy', European Economic Review 32, pp.233-267

Li, W. (1997), 'The Impact of Economic Reform on the Performance of Chinese State Enterprises 1980-1989', Financial Management 22, pp.28-41

Lipton, D. and J. Sachs (1990), 'Creating a Market Economy in Eastern Europe: The case of Poland', Brookings Papers on Economic Activity 1, pp. 75-148

Martin, S. and D. Parker (1995), 'Privatisation and Economic Performance Throughout the UK Business Cycle', Managerial and Decision Economics 16, pp.225-237

Megginson, W., R.C. Nash, J.M. Netter and A.B. Poulsen (1998), 'The Choice of Privatisation: An Empirical Analysis', Working Paper, University of Georgia, Athens, G.A.

Megginson, W.L. and J.M. Netter, (1999), 'From State to Market: A Survey of Empirical Studies on Privatisation', Working Paper, University of Georgia, Athens, G.A.

Meyendorff, A. and E.A. Snyder (1997), 'Transitional Structure of Bank Privatisations in Central Europe and Russia', Journal of Comparative Economics 25, pp.5-30

Murphy, K., A. Shliefer and R.W. Vining (1993), 'Why is Rent Seeking so Costly to Growth', American Economic Review, Papers and Proceedings, pp.409-414

Nellis, J. and S. Kikeri (1989), 'Public Enterprise Reform: Privatisation and the World Bank', World Development 17, pp.659-672

Newbery, D. (1991), 'Reform in Hungary: Sequencing and Privatisation', European Economic Review 35, pp.571-580

Pinto, B., M. Belka and S. Krajewski (1993), 'Transforming State Enterprises in Poland: Evidence on Adjustment by Manufacturing Firms', Brookings Papers on Economic Activity, pp.213-261

Pistor, K. and A. Spicer (1997), 'Investment Funds in Mass Privatisation and Beyond: Evidence from the Czech Republic and Russia', Private Sector (World Bank, December), pp.33-36

Pohl, G., R.E. Anderson, S. Claessens and S. Djankov (1997), 'Privatisation and Restructuring in Central Eastern Europe: Evidence and Policy Options', World Bank Technical Paper No.368, Washington DC

Portes, R. (1991), 'Introduction to the Path of Reform in Central Eastern Europe', Special Issue no. 2 of European Economy 
Repkine, A. and P.P. Walsh (1999), ' Evidence of European Trade and Investment UShaping Industrial Output in Bulgaria, Hungary, Poland and Romania', Journal of Comparative Economics, Vol. 27, No. 4, pp730-752, 1999.

Rodrik, D. (1994), 'Foreign trade in Eastern Europe's Transition: Early Results' in O. Blanchard, K. Froot and J. Sachs, Eds., The Transition in Eastern Europe, Vol. 2, pp.319-356. Chicago, IL: NBER and University of Chicago Press

Roland, G. (1993), 'The Political Economy of Restructuring and Privatisation in Eastern Europe', European Economic Review 37, pp.533-540

Roland, G. (1996), 'Economic Efficiency and Political Constraints in Privatisation and Restructuring', Paper presented at EBRD Workshop on "Policy Studies to Promore Private Sector Development"

Roland, G. and T. Verdier (1999), 'Transition and the Output Fall', Economics of Transition 7, pp.1-28

Shliefer, A. (1998), 'State versus Private Ownership', Journal of Economic Perspectives 12, pp.133-150

Sinn, G. and H.W. Sinn (1993), From Plan to Market: World Development Report 1996, New York: Oxford University Press

Stiglitz, J. (1999), 'Whither Reform? Ten Years of the Transition', Paper prepared for the Annual Bank Conference on Development Economics, Washington DC

Vickers, J. and G. Yarrow (1988), Privatisation, London: MIT Press

Vining, A. and A.E. Boardman (1992), 'Ownership versus Competition: Efficiency in Public Enterprise, Public Choice 73, pp.205-239

World Bank (1995), 'Bureaucrats in Business', Washington D.C.

Yarrow, G. (1986), 'Privatisation in Theory and Practice', Economic Policy 2, pp.324364 


\section{Endnotes}

1 With regard to speed and the sequencing of reforms, the "Big Bang" approach stresses the complementarity of reforms for economic consistency, as in Blanchard et al 1991, Lipton and Sachs 1990, Newbery 1991, and Portes 1991.

${ }^{2}$ The apparent failure of privatisation to insiders, as defined by workers and managers of the firm, is found in Frydman, Gray, Hessel and Rapaczynski (1999), Earle and Estrin (1996), Blanchard and Aghion (1996), Murphy, Shleifer and Vining (1993).

${ }^{3}$ The emphasis on supply side distortions as the sole determinant of the evolution of industrial output in CEE countries is found in Atkeson and Kehoe (1996), Blanchard (1997), Blanchard and Kremer (1997) and Roland and Verdier (1997). While supply side considerations may be extremely relevant when explaining the evolution of historically CMEA oriented production during transition, [see Konings and Walsh (1999) for the case of Ukraine], their constraint on the evolution of historically EU oriented production is not evident.

${ }^{4}$ Cornelli and $\mathrm{Li}$ (1997) and Katz and Owen (1993) indicate that the state may be reluctant to privatise firms to outsiders in order to protect employment.

5 Martin and Parker (1995) examine UK firms in the 1980s and find many improved in terms of performance before privatisation indicating a shake-out and restructuring of firms pre-privatisation. Li (1997) on a sample of 272 state owned Chinese firms show the benefits of the 1979 market reforms on firm performance during 1980-1989 in the absence of privatisation. Dewenter and Malatesta (1998) find that operating profits increase prior to divestiture but may decrease somewhat afterward. This is interpreted as evidence that governments efficiently restructure some firms before privatising in order to receive a higher price on privatising, although the actual change in ownership does not give rise to subsequent efficiency gains. Nellis and Kikeri (1989) suggest state restructuring pre-privatisation in order to eliminate distortions such as those arising from Trade Unions.

Megginson, Nash, Netter and Poulsen (1998) explicitly study the choice between asset sales and share issue privatisation. Empirically they find that state owned enterprises are more likely to be sold through a share offering the larger is the firm, when the company being sold is a telecom, and the more developed is the national stock market.

${ }^{6}$ For an excellent survey of empirical studies on privatisation, the reader is referred to Megginson and Netter (1999).

${ }^{7}$ Vining and Boardman 1992 show this in market economies, while Claessens, Djankov and Pohl 1997 illustrate this for transition economies.

${ }^{8}$ Many studies find no average effect of privatisation in transition countries. See for example Pinto et al, 1993.

${ }^{9}$ The first year of available trade data for Slovakia and Slovenia was 1993 and 1992 respectively. In order to derive the historical trade orientation of products for these countries therefore, it was necessary to trek the characteristics of those products exported in the first available year of data back to the corresponding trade data in 1988 for Czechoslovakia and Yugoslavia.

${ }^{10}$ The sole exception to this is the Transport Equipment sector in Bulgaria, where $1988 \mathrm{EU}$ trade oriented products only account for 20 per cent of total exports to the EU in 1996. This would suggest that there has been a reorientation of products from the CMEA to the EU market over time in this particular case.

${ }^{11}$ For detailed information about the survey content, questionnaire and methodology see Bilsen (1997).

${ }^{12}$ De Novo firms are typically much smaller than traditional firms, private upon entry. We wish to focus on the impact of privatisation on tradition firms conditioned on their initial trade orientation. We therefore exclude them from our analysis. Konings (1997) using the same data undertakes a comparison of traditional and de nova firm performance during transition.

${ }^{13}$ See Estrin (1994) for details on the privatisation methods in Central Eastern Europe. 


\section{William Davidson Institute Working Paper 338}

14 See for example, Frydman, Pistor and Rapaczynski (1996), Blanchard and Aghion (1996), Pistor and Spicer 1997, and Meyendorff and Snyder (1997).

${ }^{15}$ Transition specific difficulties in such empirical measures of performance include the presence of high and volatile inflation rates, variations in accounting standards to conform with western norms, appropriate evaluation of inherited capital stock, and tax evasion. See Bevan, Estrin, and Schaffer (1999) for a more detailed overview of these issues.

${ }^{16}$ Note that only the ownership structure of a subsample of our 220 firms can be predicted due to certain firms failing to fill in employment levels for 1992. 


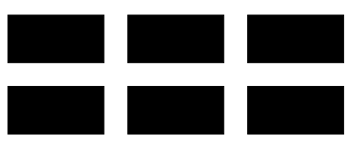

THE WILLIAM DAVIDSON INSTITUTE

AT THE UNIVERSITY OF MICHIGAN BUSINESSSCHOOL

\section{DAVIDSON INSTITUTE WORKING PAPER SERIES}

CURRENT AS OF 10/4/00

\begin{tabular}{|c|c|c|}
\hline Publication & Authors & Date of Paper \\
\hline $\begin{array}{l}\text { No. } 338 \text { Firm Performance and the Political } \\
\text { Economy of Corporate Governance: Survey } \\
\text { Evidence for Bulgaria, Hungary, Slovakia } \\
\text { and Slovenia }\end{array}$ & Patrick Paul Walsh and Ciara Whela & July 2000 \\
\hline No. 337 Investment and Instability & Nauro F. Campos and Jeffrey B. Nugent & May 2000 \\
\hline $\begin{array}{l}\text { No. } 336 \text { The Evolution of the Insurance } \\
\text { Sector in Central and Eastern Europe and } \\
\text { the former Soviet Union }\end{array}$ & Robert B.K. Pye & August 2000 \\
\hline $\begin{array}{l}\text { No. } 335 \text { Institutional Technology and the } \\
\text { Chains of Trust: Capital Markets and } \\
\text { Privatization in Russia and the Czech } \\
\text { Republic }\end{array}$ & Bruce Kogut and Andrew Spicer & August 2000 \\
\hline $\begin{array}{l}\text { No. } 334 \text { The Evolution of Market Integration } \\
\text { in Russia }\end{array}$ & Daniel Berkowitz and David N. DeJong & August 2000 \\
\hline $\begin{array}{l}\text { No. } 333 \text { Efficiency and Market Share in } \\
\text { Hungarian Corporate Sector }\end{array}$ & László Halpern and Gábor Körösi & July 2000 \\
\hline $\begin{array}{l}\text { No. } 332 \text { Search-Money-and-Barter Models of } \\
\text { Financial Stabilization }\end{array}$ & S.I. Boyarchenko and S.Z. Levendorskii & July 2000 \\
\hline $\begin{array}{l}\text { No. } 331 \text { Worker Training in a Restructuring } \\
\text { Economy: Evidence from the Russian } \\
\text { Transition }\end{array}$ & $\begin{array}{l}\text { Mark C. Berger, John S. Earle and Klara } \\
\text { Z. Sabirianova }\end{array}$ & August 2000 \\
\hline $\begin{array}{l}\text { No. 330 Economic Development in Palanpur } \\
\text { 1957-1993: A Sort of Growth }\end{array}$ & Peter Lanjouw & August 2000 \\
\hline $\begin{array}{l}\text { No. } 329 \text { Trust, Organizational Controls, } \\
\text { Knowledge Acquisition from the Foreign } \\
\text { Parents, and Performance in Vietnamese } \\
\text { International Joint Ventures }\end{array}$ & $\begin{array}{l}\text { Marjorie A. Lyles, Le Dang Doanh, and } \\
\text { Jeffrey Q. Barden }\end{array}$ & June 2000 \\
\hline $\begin{array}{l}\text { No. } 328 \text { Comparative Advertising in the } \\
\text { Global Marketplace: The Effects of Cultural } \\
\text { Orientation on Communication }\end{array}$ & $\begin{array}{l}\text { Zeynep Gürhan-Canli and Durairaj } \\
\text { Maheswaran }\end{array}$ & August 2000 \\
\hline $\begin{array}{l}\text { No. } 327 \text { Post Privatization Enterprise } \\
\text { Restructuring }\end{array}$ & Morris Bornstein & July 2000 \\
\hline No. 326 Who is Afraid of Political Instability? & Nauro F. Campos and Jeffrey B. Nugent & July 2000 \\
\hline $\begin{array}{l}\text { No. } 325 \text { Business Groups, the Financial } \\
\text { Market and Modernization }\end{array}$ & Raja Kali & June 2000 \\
\hline $\begin{array}{l}\text { No. } 324 \text { Restructuring with What Success? A } \\
\text { Case Study of Russian Firms }\end{array}$ & Susan Linz & July 2000 \\
\hline $\begin{array}{l}\text { No. } 323 \text { Priorities and Sequencing in } \\
\text { Privatization: Theory and Evidence from the } \\
\text { Czech Republic }\end{array}$ & $\begin{array}{l}\text { Nandini Gupta, John C. Ham and Jan } \\
\text { Svejnar }\end{array}$ & May 2000 \\
\hline $\begin{array}{l}\text { No. } 322 \text { Liquidity, Volatility, and Equity } \\
\text { Trading Costs Across Countries and Over } \\
\text { Time }\end{array}$ & $\begin{array}{l}\text { Ian Domowitz, Jack Glen and Ananth } \\
\text { Madhavan }\end{array}$ & March 2000 \\
\hline $\begin{array}{l}\text { No. } 321 \text { Equilibrium Wage Arrears: } \\
\text { Institutional Lock-In of Contractual Failure in } \\
\text { Russia }\end{array}$ & John S. Earle and Klara Z. Sabirianova & June 2000 \\
\hline
\end{tabular}

Working Papers are available at:

www.wdi.bus.umich.edu 


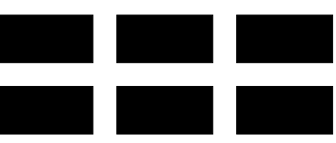

THE WILLIAM DAVIDSON INSTITUTE AT THE UNIVERSITY OF MICHIGAN BUSINESSSCHOOL

\begin{tabular}{|c|c|c|}
\hline $\begin{array}{l}\text { No. } 320 \text { Rethinking Marketing Programs for } \\
\text { Emerging Markets }\end{array}$ & Niraj Dawar and Amitava Chattopadhyay & June 2000 \\
\hline $\begin{array}{l}\text { No. } 319 \text { Public Finance and Low Equilibria in } \\
\text { Transition Economies; the Role of Institutions }\end{array}$ & Daniel Daianu and Radu Vranceanu & June 2000 \\
\hline $\begin{array}{l}\text { No. } 318 \text { Some Econometric Evidence on the } \\
\text { Effectiveness of Active Labour Market } \\
\text { Programmes in East Germany }\end{array}$ & Martin Eichler and Michael Lechner & June 2000 \\
\hline $\begin{array}{l}\text { No. } 317 \text { A Model of Russia’s “Virtual } \\
\text { Economy” }\end{array}$ & R.E Ericson and B.W Ickes & May 2000 \\
\hline $\begin{array}{l}\text { No. } 316 \text { Financial Institutions, Financial } \\
\text { Contagion, and Financial Crises }\end{array}$ & Haizhou Huang and Chenggang Xu & March 2000 \\
\hline $\begin{array}{l}\text { No. } 315 \text { Privatization versus Regulation in } \\
\text { Developing Economies: The Case of West } \\
\text { African Banks }\end{array}$ & $\begin{array}{l}\text { Jean Paul Azam, Bruno Biais, and } \\
\text { Magueye Dia }\end{array}$ & February 2000 \\
\hline $\begin{array}{l}\text { No. } 314 \text { Is Life More Risky in the Open? } \\
\text { Household Risk-Coping and the Opening of } \\
\text { China's Labor Markets }\end{array}$ & John Giles & April 2000 \\
\hline $\begin{array}{l}\text { No. } 313 \text { Networks, Migration and Investment: } \\
\text { Insiders and Outsiders in Tirupur's } \\
\text { Production Cluster }\end{array}$ & Abhijit Banerjee and Kaivan Munshi & March 2000 \\
\hline $\begin{array}{l}\text { No. } 312 \text { Computational Analysis of the Impact } \\
\text { on India of the Uruguay Round and the } \\
\text { Forthcoming WTO Trade Negotiations }\end{array}$ & $\begin{array}{l}\text { Rajesh Chadha, Drusilla K. Brown, Alan } \\
\text { V. Deardorff and Robert M. Stern }\end{array}$ & March 2000 \\
\hline $\begin{array}{l}\text { No. } 311 \text { Subsidized Jobs for Unemployed } \\
\text { Workers in Slovakia }\end{array}$ & Jan. C. van Ours & May 2000 \\
\hline $\begin{array}{l}\text { No. } 310 \text { Determinants of Managerial Pay in } \\
\text { the Czech Republic }\end{array}$ & $\begin{array}{l}\text { Tor Eriksson, Jaromir Gottvald and Pavel } \\
\text { Mrazek }\end{array}$ & May 2000 \\
\hline $\begin{array}{l}\text { No. } 309 \text { The Great Human Capital } \\
\text { Reallocation: An Empirical Analysis of } \\
\text { Occupational Mobility in Transitional Russia }\end{array}$ & Klara Z. Sabirianova & May 2000 \\
\hline $\begin{array}{l}\text { No. } 308 \text { Economic Development, Legality, and } \\
\text { the Transplant Effect }\end{array}$ & $\begin{array}{l}\text { Daniel Berkowitz, Katharina Pistor, and } \\
\text { Jean-Francois Richard }\end{array}$ & February 2000 \\
\hline $\begin{array}{l}\text { No. } 307 \text { Community Participation, Teacher } \\
\text { Effort, and Educational Outcome: The Case of } \\
\text { El Salvador's EDUCO Program }\end{array}$ & Yasuyuki Sawada & November 1999 \\
\hline $\begin{array}{l}\text { No. } 306 \text { Gender Wage Gap and Segregation in } \\
\text { Late Transition }\end{array}$ & Stepan Jurajda & May 2000 \\
\hline $\begin{array}{l}\text { No. } 305 \text { The Gender Pay Gap in the } \\
\text { Transition from Communism: Some Empirical } \\
\text { Evidence }\end{array}$ & Andrew Newell and Barry Reilly & May 2000 \\
\hline $\begin{array}{l}\text { No. } 304 \text { Post-Unification Wage Growth in } \\
\text { East Germany }\end{array}$ & Jennifer Hunt & November 1998 \\
\hline $\begin{array}{l}\text { No. } 303 \text { How Does Privatization Affect } \\
\text { Workers? The Case of the Russian Mass } \\
\text { Privatization Program }\end{array}$ & Elizabeth Brainerd & May 2000 \\
\hline $\begin{array}{l}\text { No. } 302 \text { Liability for Past Environmental } \\
\text { Contamination and Privatization }\end{array}$ & Dietrich Earnhart & March 2000 \\
\hline No. 301 Varieties, Jobs and EU Enlargement & Tito Boeri and Joaquim Oliveira Martins & May 2000 \\
\hline No. 300 Employer Size Effects in Russia & Todd Idson & April 2000 \\
\hline $\begin{array}{l}\text { No. } 299 \text { Information Complements, } \\
\text { Substitutes, and Strategic Product Design }\end{array}$ & $\begin{array}{l}\text { Geoffrey G. Parker and Marshall W. Van } \\
\text { Alstyne }\end{array}$ & March 2000 \\
\hline
\end{tabular}

Working Papers are available at:

www.wdi.bus.umich.edu 


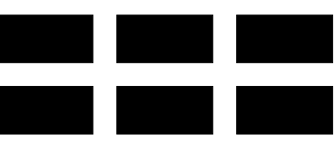

THE WILliam DAVIDSON InSTITUTE AT THE UNIVERSITY OF MICHIGAN BUSINESSSCHOOL

\begin{tabular}{|c|c|c|}
\hline $\begin{array}{l}\text { No. } 298 \text { Markets, Human Capital, and } \\
\text { Inequality: Evidence from Rural China }\end{array}$ & $\begin{array}{l}\text { Dwayne Benjamin, Loren Brandt, Paul } \\
\text { Glewwe, and Li Guo }\end{array}$ & May 2000 \\
\hline $\begin{array}{l}\text { No. } 297 \text { Corporate Governance in the Asian } \\
\text { Financial Crisis }\end{array}$ & $\begin{array}{l}\text { Simon Johnson, Peter Boone, Alasdair } \\
\text { Breach, and Eric Friedman }\end{array}$ & November 1999 \\
\hline $\begin{array}{l}\text { No. } 296 \text { Competition and Firm Performance: } \\
\text { Lessons from Russia }\end{array}$ & J. David Brown and John S. Earle & March 2000 \\
\hline $\begin{array}{l}\text { No. } 295 \text { Wage Determination in Russia: An } \\
\text { Econometric Investigation }\end{array}$ & Peter J. Luke and Mark E. Schaffer & March 2000 \\
\hline $\begin{array}{l}\text { No. 294: Can Banks Promote Enterprise } \\
\text { Restructuring?: Evidence From a Polish } \\
\text { Bank's Experience }\end{array}$ & John P. Bonin and Bozena Leven & March 2000 \\
\hline $\begin{array}{l}\text { No. 293: Why do Governments Sell Privatised } \\
\text { Companies Abroad? }\end{array}$ & $\begin{array}{l}\text { Bernardo Bortolotti, Marcella Fantini and } \\
\text { Carlo Scarpa }\end{array}$ & March 2000 \\
\hline $\begin{array}{l}\text { No. 292: Going Public in Poland: Case-by- } \\
\text { Case Privatizations, Mass Privatization and } \\
\text { Private Sector Initial Public Offerings }\end{array}$ & Wolfgang Aussenegg & December 1999 \\
\hline $\begin{array}{l}\text { No. 291: Institutional Technology and the } \\
\text { Chains of Trust: Capital Markets and } \\
\text { Privatization in Russia and the Czech } \\
\text { Republic }\end{array}$ & Bruce Kogut and Andrew Spicer & March 1999 \\
\hline $\begin{array}{l}\text { No. 290: Banking Crises and Bank Rescues: } \\
\text { The Effect of Reputation }\end{array}$ & Jenny Corbett and Janet Mitchell & January 2000 \\
\hline $\begin{array}{l}\text { No. 289: Do Active Labor Market Policies } \\
\text { Help Unemployed Workers to Find and Keep } \\
\text { Regular Jobs? }\end{array}$ & Jan C. van Ours & February 2000 \\
\hline $\begin{array}{l}\text { No. 288: Consumption Patterns of the New } \\
\text { Elite in Zimbabwe }\end{array}$ & Russell Belk & February 2000 \\
\hline $\begin{array}{l}\text { No. 287: Barter in Transition Economies: } \\
\text { Competing Explanations Confront Ukranian } \\
\text { Data }\end{array}$ & $\begin{array}{l}\text { Dalia Marin, Daniel Kaufmann and } \\
\text { Bogdan Gorochowskij }\end{array}$ & January 2000 \\
\hline $\begin{array}{l}\text { No. 286: The Quest for Pension Reform: } \\
\text { Poland's Security through Diversity }\end{array}$ & Marek Góra and Michael Rutkowski & January 2000 \\
\hline $\begin{array}{l}\text { No. 285: Disorganization and Financial } \\
\text { Collapse }\end{array}$ & Dalia Marin and Monika Schnitzer & October 1999 \\
\hline $\begin{array}{l}\text { No. 284: Coordinating Changes in M-form } \\
\text { and U-form Organizations }\end{array}$ & $\begin{array}{l}\text { Yingyi Qian, Gérard Roland and } \\
\text { Chenggang } X u\end{array}$ & May 1999 \\
\hline $\begin{array}{l}\text { No. 283: Why Russian Workers Do Not Move: } \\
\text { Attachment of Workers Through In-Kind } \\
\text { Payments }\end{array}$ & Guido Friebel and Sergei Guriev & October 1999 \\
\hline $\begin{array}{l}\text { No. 282: Lessons From Fiascos in Russian } \\
\text { Corporate Governance }\end{array}$ & Merritt B. Fox and Michael A. Heller & October 1999 \\
\hline $\begin{array}{l}\text { No. 281: Income Distribution and Price } \\
\text { Controls: Targeting a Social Safety Net } \\
\text { During Economic Transition }\end{array}$ & Michael Alexeev and James Leitzel & March 1999 \\
\hline $\begin{array}{l}\text { No. 280: Starting Positions, Reform Speed, } \\
\text { and Economic Outcomes in Transitioning } \\
\text { Economies }\end{array}$ & William Hallagan and Zhang Jun & January 2000 \\
\hline No. 279: The Value of Prominent Directors & Yoshiro Miwa \& J. Mark Ramseyer & October 1999 \\
\hline No. 278: The System Paradigm & János Kornai & April 1998 \\
\hline $\begin{array}{l}\text { No. 277: The Developmental Consequences of } \\
\text { Foreign Direct Investment in the Transition }\end{array}$ & Lawrence Peter King & September 1999 \\
\hline
\end{tabular}

Working Papers are available at:

www.wdi.bus.umich.edu 


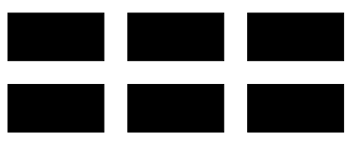

THE WILLIAM DAVIDSON INSTITUTE AT THE UNIVERSITY OF MICHIGAN BUSINESSSCHOOL

\begin{tabular}{|c|c|c|}
\hline $\begin{array}{l}\text { from Socialism to Capitalism: The } \\
\text { Performance of Foreign Owned Firms in } \\
\text { Hungary }\end{array}$ & & \\
\hline $\begin{array}{l}\text { No. 276: Stability and Disorder: An } \\
\text { Evolutionary Analysis of Russia's Virtual } \\
\text { Economy }\end{array}$ & Clifford Gaddy and Barry W. Ickes & November 1999 \\
\hline $\begin{array}{l}\text { No. 275: Limiting Government Predation } \\
\text { Through Anonymous Banking: A Theory with } \\
\text { Evidence from China. }\end{array}$ & $\begin{array}{l}\text { Chong-En Bai, David D. Li, Yingyi Qian } \\
\text { and Yijiang Wang }\end{array}$ & July 1999 \\
\hline No. 274: Transition with Labour Supply & Tito Boeri & December 1999 \\
\hline $\begin{array}{l}\text { No. 273: Sectoral Restructuring and Labor } \\
\text { Mobility: A Comparative Look at the Czech } \\
\text { Republic }\end{array}$ & Vit Sorm and Katherine Terrell & November 1999 \\
\hline $\begin{array}{l}\text { No. 272: Published in: Journal of } \\
\text { Comparative Economics "Returns to Human } \\
\text { Capital Under the Communist Wage Grid and } \\
\text { During the Transition to a Market Economy" } \\
\text { Vol. 27, pp. 33-60 1999. }\end{array}$ & $\begin{array}{l}\text { Daniel Munich, Jan Svejnar and Katherine } \\
\text { Terrell }\end{array}$ & October 1999 \\
\hline $\begin{array}{l}\text { No. 271: Barter in Russia: Liquidity Shortage } \\
\text { Versus Lack of Restructuring }\end{array}$ & Sophie Brana and Mathilde Maurel & June 1999 \\
\hline $\begin{array}{l}\text { No. 270: Tests for Efficient Financial } \\
\text { Intermediation with Application to China }\end{array}$ & Albert Park and Kaja Sehrt & March 1999 \\
\hline $\begin{array}{l}\text { No. 269a: Russian Privatization and } \\
\text { Corporate Governance: What Went Wrong? }\end{array}$ & $\begin{array}{l}\text { Bernard Black, Reinier Kraakman and } \\
\text { Anna Tarassova }\end{array}$ & May 2000 \\
\hline $\begin{array}{l}\text { No. 269: Russian Privatization and Corporate } \\
\text { Governance: What Went Wrong? }\end{array}$ & $\begin{array}{l}\text { Bernard Black, Reinier Kraakman and } \\
\text { Anna Tarassova }\end{array}$ & September 1999 \\
\hline $\begin{array}{l}\text { No. 268: Are Russians Really Ready for } \\
\text { Capitalism? }\end{array}$ & Susan Linz & September 1999 \\
\hline $\begin{array}{l}\text { No. 267: Do Stock Markets Promote } \\
\text { Economic Growth? }\end{array}$ & $\begin{array}{l}\text { Randall K. Filer, Jan Hanousek and Nauro } \\
\text { Campos }\end{array}$ & September 1999 \\
\hline $\begin{array}{l}\text { No. 266: Objectivity, Proximity and } \\
\text { Adaptability in Corporate Governance }\end{array}$ & Arnoud W.A Boot and Jonathan R. Macey & September 1999 \\
\hline $\begin{array}{l}\text { No. 265: When the Future is not What it Used } \\
\text { to Be: Lessons from the Western European } \\
\text { Experience to Forecasting Education and } \\
\text { Training in Transitional Economies }\end{array}$ & $\begin{array}{l}\text { Nauro F. Campos, Gerard Hughes, Stepan } \\
\text { Jurajda, and Daniel Munich }\end{array}$ & September 1999 \\
\hline $\begin{array}{l}\text { No. 264: The Institutional Foundation of } \\
\text { Foreign-Invested Enterprises (FIEs) in China }\end{array}$ & Yasheng Huang & September 1999 \\
\hline $\begin{array}{l}\text { No. 263: The Changing Corporate } \\
\text { Governance Paradigm: Implications for } \\
\text { Transition and Developing Countries }\end{array}$ & $\begin{array}{l}\text { Erik Berglof and Ernst-Ludwig von } \\
\text { Thadden }\end{array}$ & June 1999 \\
\hline No. 262: Law Enforcement and Transition & Gerard Roland and Thierry Verdier & May 1999 \\
\hline $\begin{array}{l}\text { No. 261: Soft Budget Constraints, Pecuniary } \\
\text { Externality, and the Dual Track System }\end{array}$ & Jiahua Che & June 2000 \\
\hline $\begin{array}{l}\text { No. 260: Missing Market in Labor Quality: } \\
\text { The Role of Quality Markets in Transition }\end{array}$ & Gary H. Jefferson & July 1999 \\
\hline $\begin{array}{l}\text { No. 259: Do Corporate Global Environmental } \\
\text { Standards in Emerging Markets Create or } \\
\text { Destroy Market Value }\end{array}$ & $\begin{array}{l}\text { Glen Dowell, Stuart Hart and Bernard } \\
\text { Yeung }\end{array}$ & June 1999 \\
\hline
\end{tabular}

Working Papers are available at:

www.wdi.bus.umich.edu 


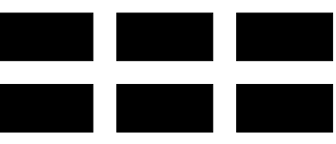

THE WILLIAM DAVIDSON INSTITUTE

AT THE UNIVERSITY OF MICHIGAN BUSINESSSCHOOL

\begin{tabular}{|c|c|c|}
\hline $\begin{array}{l}\text { No. 258: Public Training and Outflows from } \\
\text { Unemployment }\end{array}$ & Patrick A. Puhani & June 1999 \\
\hline $\begin{array}{l}\text { No. 257: Ownership Versus Environment: } \\
\text { Why are Public Sector Firms Inefficient? }\end{array}$ & Ann P. Bartel and Ann E. Harrison & June 1999 \\
\hline $\begin{array}{l}\text { No. 256: Taxation and Evasion in the } \\
\text { Presence of Exortion by Organized Crime }\end{array}$ & $\begin{array}{l}\text { Michael Alexeev, Eckhard Janeba and } \\
\text { Stefan Osborne }\end{array}$ & November 1999 \\
\hline $\begin{array}{l}\text { No. 255: Revisiting Hungary's Bankruptcy } \\
\text { Episode }\end{array}$ & John P. Bonin and Mark E. Schaffer & September 1999 \\
\hline $\begin{array}{l}\text { No. 254: FDI in Emerging Markets: A Home- } \\
\text { Country View }\end{array}$ & Marina v.N Whitman & June 1999 \\
\hline $\begin{array}{l}\text { No. 253: The Asian Financial Crisis: What } \\
\text { Happened, and What is to be Done }\end{array}$ & Jeffrey D. Sachs and Wing Thye Woo & January 1999 \\
\hline $\begin{array}{l}\text { No. 252: Organizational Law as Asset } \\
\text { Partitioning }\end{array}$ & Henry Hansmann and Reinier Kraakman & September 1999 \\
\hline $\begin{array}{l}\text { No. 251: Consumer Behavior Research in } \\
\text { Emerging Consumer Markets: the Case of the } \\
\text { Optimum Stimulation Level in South Africa }\end{array}$ & $\begin{array}{l}\text { Jan-Benedict E. M. Steenkamp and Steven } \\
\text { M. Burgess }\end{array}$ & September 1999 \\
\hline $\begin{array}{l}\text { No. 250: Property Rights Formation and the } \\
\text { Organization of Exchange and Production in } \\
\text { Rural China }\end{array}$ & $\begin{array}{l}\text { Matthew A. Turner, Loren Brandt, and } \\
\text { Scott Rozelle }\end{array}$ & July 1998 \\
\hline $\begin{array}{l}\text { No. 249: Impacts of the Indonesian Economic } \\
\text { Crisis: Price Changes and the Poor }\end{array}$ & $\begin{array}{l}\text { James Levinsohn, Steven Berry, and Jed } \\
\text { Friedman }\end{array}$ & June 1999 \\
\hline $\begin{array}{l}\text { No. 248: Internal Barriers in the Transition of } \\
\text { Enterprises from Central Plan to Market }\end{array}$ & Charalambos Vlachoutsicos & July 1999 \\
\hline $\begin{array}{l}\text { No. 247: Spillovers from Multinationals in } \\
\text { Developing Countries: the Mechanisms at } \\
\text { Work }\end{array}$ & Richard E. Caves & June 1999 \\
\hline $\begin{array}{l}\text { No. 246: Dynamism and Inertia on the } \\
\text { Russian Labour Market: A Model of } \\
\text { Segmentation }\end{array}$ & $\begin{array}{l}\text { Irena Grosfeld, Claudia Senik-Leygonie, } \\
\text { Thierry Verdier, Stanislav Kolenikov and } \\
\text { Elena Paltseva }\end{array}$ & May 1999 \\
\hline $\begin{array}{l}\text { No. 245: Lessons from Bank Privatization in } \\
\text { Central Europe }\end{array}$ & John Bonin and Paul Wachtel & May 1999 \\
\hline $\begin{array}{l}\text { No. 244: Nominal-Real Tradeoffs and the } \\
\text { Effects of Monetary Policy: the Romanian } \\
\text { Experience }\end{array}$ & Christian Popa & December 1998 \\
\hline $\begin{array}{l}\text { No. 243: Privatization, Political Risk and } \\
\text { Stock Market Development in Emerging } \\
\text { Economies }\end{array}$ & Enrico C. Perotti and Pieter van Oijen & March 1999 \\
\hline $\begin{array}{l}\text { No. 242: Investment Financing in Russian } \\
\text { Financial-Industrial Groups }\end{array}$ & Enrico C. Perotti and Stanislav Gelfer & October 1998 \\
\hline $\begin{array}{l}\text { No. 241: Can governments maintain hard } \\
\text { budget constraints? Bank lending and } \\
\text { financial isolation in Romania }\end{array}$ & $\begin{array}{l}\text { Octavian Carare, Constantijn Claessens, } \\
\text { Enrico C. Perotti }\end{array}$ & January 1999 \\
\hline $\begin{array}{l}\text { No. 240: Democratic Institutions and } \\
\text { Economic Reform: the Polish Case }\end{array}$ & $\begin{array}{l}\text { John E. Jackson, Jacek Klich, and } \\
\text { Krystyna Poznanska }\end{array}$ & April 1998 \\
\hline $\begin{array}{l}\text { No. 239: A Longitudinal Study of IJV } \\
\text { Performance in Eastern Europe }\end{array}$ & Keith D. Brouthers and Gary Bamossy & June 1999 \\
\hline $\begin{array}{l}\text { No. 238: Published in: Journal of Business } \\
\text { Venturing, "Firm Creation and Economic } \\
\text { Transitions", Vol. 14, Iss. 5,6 Sep/Nov 1999, } \\
\text { pp. 427-450. }\end{array}$ & $\begin{array}{l}\text { John E. Jackson, Jacek Klich, Krystyna } \\
\text { Poznanska }\end{array}$ & July 1998 \\
\hline No. 237: Analysis of Entrepreneurial Attitudes & John E. Jackson and Aleksander S. & March 1997 \\
\hline
\end{tabular}

Working Papers are available at:

www.wdi.bus.umich.edu 


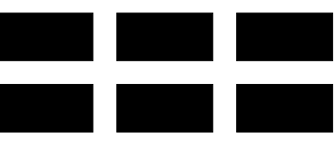

THE WILLIAM DAVIDSON INSTITUTE AT THE UNIVERSITY OF MICHIGAN BUSINESSSCHOOL

\begin{tabular}{|c|c|c|}
\hline in Poland & Marcinkowski & \\
\hline $\begin{array}{l}\text { No. 236: Investment and Finance in De Novo } \\
\text { Private Firms: Empirical Results from the } \\
\text { Czech Republic, Hungary, and Poland }\end{array}$ & $\begin{array}{l}\text { Andrzej Bratkowski, Irena Grosfeld, Jacek } \\
\text { Rostowski }\end{array}$ & April 1999 \\
\hline $\begin{array}{l}\text { No. 235: Does a Soft Macroeconomic } \\
\text { Environment Induce Restructuring on the } \\
\text { Microeconomic Level during the Transition } \\
\text { Period? Evidence from Investment Behavior } \\
\text { of Czech Enterprises }\end{array}$ & Lubomír Lizal & June 1999 \\
\hline $\begin{array}{l}\text { No. 234: Banking Reform in China: Gradually } \\
\text { Strengthening Pillar or Fragile Reed? }\end{array}$ & John Bonin & June 1999 \\
\hline $\begin{array}{l}\text { No. 233: Theories of Soft Budget Constraints } \\
\text { and the Analysis of Banking Crises }\end{array}$ & Janet Mitchell & March 1999 \\
\hline $\begin{array}{l}\text { No. 232: Unemployment Risk, Precautionary } \\
\text { Savings, and Moonlighting in Russia }\end{array}$ & $\begin{array}{l}\text { Alessandra Guariglia and Byung-Yeon } \\
\text { Kim }\end{array}$ & June 1999 \\
\hline $\begin{array}{l}\text { No. 231: Investing in Turbulent Times: The } \\
\text { Investment Behavior of Polish Firms in the } \\
\text { Transition }\end{array}$ & $\begin{array}{l}\text { Josef C. Brada, Arthur E. King, and Chia- } \\
\text { Ying Ma }\end{array}$ & April 1999 \\
\hline $\begin{array}{l}\text { No. 230: The End of Moderate Inflation in } \\
\text { Three Transition Economies? }\end{array}$ & Josef C. Brada and Ali M. Kutan & April 1999 \\
\hline $\begin{array}{l}\text { No. 229: Back to the Future: The Growth } \\
\text { Prospects of Transition Economies } \\
\text { Reconsidered }\end{array}$ & Nauro F. Campos & April 1999 \\
\hline $\begin{array}{l}\text { No. 228: The Enterprise Isolation Program in } \\
\text { Russia }\end{array}$ & Simeon Djankov & April 1999 \\
\hline $\begin{array}{l}\text { No. 227: Published in: Journal of } \\
\text { Comparative Economics, “Ownership } \\
\text { Concentration and Corporate Performance in } \\
\text { the Czech Republic” 27(3), September 1999, } \\
\text { pp. 498-513. }\end{array}$ & Stijn Claessens and Simeon Djankov & April 1999 \\
\hline $\begin{array}{l}\text { No. 226: Unemployment Benefit Entitlement } \\
\text { and Training Effects in Poland during } \\
\text { Transition }\end{array}$ & Patrick A. Puhani & March 1999 \\
\hline $\begin{array}{l}\text { No. 225: Transition at Whirlpool-Tatramat: } \\
\text { Case Studies }\end{array}$ & Hans Brechbuhl and Sonia Ferencikova & March 1999 \\
\hline $\begin{array}{l}\text { No. 224: Measuring Progress in Transition } \\
\text { and Towards EU Accession: A Comparison of } \\
\text { Manufacturing Firms in Poland, Romania, } \\
\text { and Spain }\end{array}$ & $\begin{array}{l}\text { Wendy Carlin, Saul Estrin, and Mark } \\
\text { Schaffer }\end{array}$ & March 1999 \\
\hline $\begin{array}{l}\text { No. 223: Product Market Competition in } \\
\text { Transition Economies: Increasing Varieties } \\
\text { and Consumer Loyalty }\end{array}$ & Mitsutoshi M. Adachi & March 1999 \\
\hline $\begin{array}{l}\text { No. 222: Opaque Markets and Rapid Growth: } \\
\text { the Superiority of Bank-Centered Financial } \\
\text { Systems for Developing Nations }\end{array}$ & Rodney Wallace & July 1999 \\
\hline $\begin{array}{l}\text { No. 221: Technology Spillovers through } \\
\text { Foreign Direct Investment }\end{array}$ & Yuko Kinoshita & January 1999 \\
\hline $\begin{array}{l}\text { No. 220: Managerial, Expertise and Team } \\
\text { Centered Forms of Organizing: A Cross- } \\
\text { Cultural Exploration of Independence in } \\
\text { Engineering Work }\end{array}$ & Leslie Perlow & January 1999 \\
\hline No. 219: Household Structure and Labor & Audra J. Bowlus and Terry Sicular & January 1999 \\
\hline
\end{tabular}

Working Papers are available at:

www.wdi.bus.umich.edu 


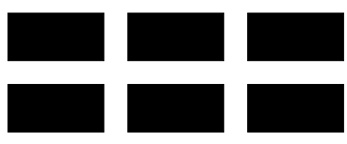

THE WILLIAM DAVIDSON INSTITUTE AT THE UNIVERSITY OF MICHIGAN BUSINESSSCHOOL

\begin{tabular}{|c|c|c|}
\hline $\begin{array}{l}\text { Demand in Agriculture: Testing for } \\
\text { Separability in Rural China }\end{array}$ & & \\
\hline $\begin{array}{l}\text { No. 218: Competing Strategies of FDI and } \\
\text { Technology Transfer to China: American and } \\
\text { Japanese Firms }\end{array}$ & W. Mark Fruin and Penelope Prime & January 1999 \\
\hline $\begin{array}{l}\text { No. } 217 \text { Published in: Journal of } \\
\text { Comparative Economics, "Returns to } \\
\text { Mobility in the Transition to a Market } \\
\text { Economy" Vol. 27, No. 1, March 1999, pp. 4- }\end{array}$ & Tito Boeri and Christopher J. Flinn & January 1999 \\
\hline $\begin{array}{l}\text { No. } 216 \text { Published in: Journal of } \\
\text { Comparative Economics, "Labor Market } \\
\text { Policies and Unemployment in the Czech } \\
\text { Republic." Vol. 27, No. 1, March 1999, pp. } \\
\text { 33-60. }\end{array}$ & Katherine Terrell and Vit Sorm & November 1998 \\
\hline $\begin{array}{l}\text { No. } 215 \text { Published in: Journal of } \\
\text { Comparative Economics, “Active Labor } \\
\text { Market Policies in Poland: Human Capital } \\
\text { Enhancement, Stigmatization or Benefit } \\
\text { Churning?" Vol. 27, No. 1, March 1999, pp. } \\
61-\end{array}$ & $\begin{array}{l}\text { Jochen Kluve, Hartmut Lehmann, and } \\
\text { Christoph M. Schmidt }\end{array}$ & December 1998 \\
\hline $\begin{array}{l}\text { No. } 214 \text { Published in: Journal of } \\
\text { Comparative Economics, “Does the Slovenian } \\
\text { Public Work Program Increase Participants' } \\
\text { Chances to Find a Job?” Vol. 27, No.1, } \\
\text { March 1999, pp. 113- }\end{array}$ & Milan Vodopivec & December 1998 \\
\hline $\begin{array}{l}\text { No. } 213 \text { Published in: Journal of } \\
\text { Comparative Economics, "Effects of Active } \\
\text { Labor Market Programs on the Transition } \\
\text { Rate from Unemployment into Regular Jobs in } \\
\text { the Slovak Republic." Vol. 27, No. 1, March } \\
\text { 1999, pp. 90- }\end{array}$ & Martina Lubyova and Jan C. van Ours & December 1998 \\
\hline $\begin{array}{l}\text { No. 212: The Marketing System in Bulgarian } \\
\text { Livestock Production - The Present State and } \\
\text { Evolutionary Processes During the Period of } \\
\text { Economic Transition }\end{array}$ & Yordan Staykov, Team Leader & October 1998 \\
\hline $\begin{array}{l}\text { No. 211: Bankruptcy Experience in Hungary } \\
\text { and the Czech Republic }\end{array}$ & Janet Mitchell & October 1998 \\
\hline $\begin{array}{l}\text { No 210: Values, Optimum Stimulation Levels } \\
\text { and Brand Loyalty: New Scales in New } \\
\text { Populations }\end{array}$ & Steven M. Burgess and Mari Harris & September 1998 \\
\hline $\begin{array}{l}\text { No. 209: Inherited Wealth, Corporate Control } \\
\text { and Economic Growth }\end{array}$ & $\begin{array}{l}\text { Randall K. Morck, David A. Stangeland, } \\
\text { and Bernard Yeung }\end{array}$ & September 1998 \\
\hline $\begin{array}{l}\text { No. 208: A Cultural Analysis of Homosocial } \\
\text { Reproduction and Contesting Claims to } \\
\text { Competence in Transitional Firms }\end{array}$ & Michael D. Kennedy & July 1998 \\
\hline $\begin{array}{l}\text { No. 207: From Survival to Success: The } \\
\text { Journey of Corporate Transformation at } \\
\text { Haier. Forthcoming in Teaching the } \\
\text { Dinosaurs to Dance: Organizational Change } \\
\text { in Transition Economies ed. Daniel Denison. }\end{array}$ & Arthur Yeung and Kenneth DeWoskin & July 1998 \\
\hline $\begin{array}{l}\text { No. 206: Why Do People Work If They Are } \\
\text { Not Paid? An Example from Eastern Europe. }\end{array}$ & Irina L. Zinovieva & May 1998 \\
\hline
\end{tabular}

Working Papers are available at: www.wdi.bus.umich.edu 


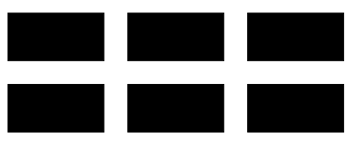

THE WILLIAM DAVIDSON INSTITUTE

AT THE UNIVERSITY OF MICHIGAN BUSINESSSCHOOL

\begin{tabular}{|c|c|c|}
\hline $\begin{array}{l}\text { Forthcoming in Teaching the Dinosaurs to } \\
\text { Dance: Organizational Change in Transition } \\
\text { Economies ed. Daniel Denison. }\end{array}$ & & \\
\hline $\begin{array}{l}\text { No. 205: Firm Ownership and Work } \\
\text { Motivation in Bulgaria and Hungary: An } \\
\text { Empirical Study of the Transition in the Mid- } \\
\text { 1990s. Forthcoming in Teaching the } \\
\text { Dinosaurs to Dance: Organizational Change } \\
\text { in Transition Economies ed. Daniel Denison. }\end{array}$ & $\begin{array}{l}\text { Robert A. Roe, Irina L. Zinovieva, } \\
\text { Elizabeth Dienes, and Laurens A. ten Horn }\end{array}$ & May 1998 \\
\hline $\begin{array}{l}\text { No. 204: Human Resource Management in the } \\
\text { Restructuring of Chinese Joint Ventures. } \\
\text { Forthcoming in Teaching the Dinosaurs to } \\
\text { Dance: Organizational Change in Transition } \\
\text { Economies ed. Daniel Denison. }\end{array}$ & Nandani Lynton & April 1998 \\
\hline $\begin{array}{l}\text { No. 203: Emergent Compensation Strategies } \\
\text { in Post-Socialist Poland: Understanding the } \\
\text { Cognitive Underpinnings of Management } \\
\text { Practices in a Transition Economy. } \\
\text { Forthcoming in Teaching the Dinosaurs to } \\
\text { Dance: Organizational Change in Transition } \\
\text { Economies ed. Daniel Denison. }\end{array}$ & Marc Weinstein & March 1998 \\
\hline $\begin{array}{l}\text { No. 202: Corporate Transformation and } \\
\text { Organizational Learning: The People's } \\
\text { Republic of China. Forthcoming in Teaching } \\
\text { the Dinosaurs to Dance: Organizational } \\
\text { Change in Transition Economies ed. Daniel } \\
\text { Denison. }\end{array}$ & Meinolf Dierkes and Zhang Xinhua & March 1998 \\
\hline $\begin{array}{l}\text { No. 201: Foreign Direct Investment as a } \\
\text { Factor of Change: The Case of Slovakia. } \\
\text { Forthcoming in Teaching the Dinosaurs to } \\
\text { Dance: Organizational Change in Transition } \\
\text { Economies ed. Daniel Denison. }\end{array}$ & Sonia Ferencikova & February 1998 \\
\hline $\begin{array}{l}\text { No. 200: Radical versus Incremental Change: } \\
\text { The Role of Capabilities, Competition, and } \\
\text { Leaders. Forthcoming in Teaching the } \\
\text { Dinosaurs to Dance: Organizational Change } \\
\text { in Transition Economies ed. Daniel Denison. }\end{array}$ & Karen L. Newman & February 1998 \\
\hline $\begin{array}{l}\text { No. 199: The Emergence of Market Practices } \\
\text { in China's Economic Transition: Price Setting } \\
\text { Practices in Shanghai's Industrial Firms. } \\
\text { Forthcoming in Teaching the Dinosaurs to } \\
\text { Dance: Organizational Change in Transition } \\
\text { Economies ed. Daniel Denison. }\end{array}$ & Douglas Guthrie & February 1998 \\
\hline $\begin{array}{l}\text { No. 198: The Application of Change } \\
\text { Management Methods at Business } \\
\text { Organizations Operating in Hungary: } \\
\text { Challenges in the Business and Cultural } \\
\text { Environment and First Practical Experiences. } \\
\text { Forthcoming in Teaching the Dinosaurs to } \\
\text { Dance: Organizational Change in Transition } \\
\text { Economies ed. Daniel Denison. }\end{array}$ & Dr. János Fehér & January 1998 \\
\hline No. 197: Organizational Changes in Russian & Igor B. Gurkov & January 1998 \\
\hline
\end{tabular}

Working Papers are available at:

www.wdi.bus.umich.edu 


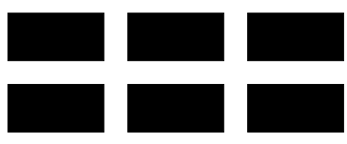

THE WILLIAM DAVIDSON INSTITUTE

AT THE UNIVERSITY OF MICHIGAN BUSINESSSCHOOL

\begin{tabular}{|c|c|c|}
\hline $\begin{array}{l}\text { Industrial Enterprises: Mutation of Decision- } \\
\text { Making Structures and Transformations of } \\
\text { Ownership. Forthcoming in Teaching the } \\
\text { Dinosaurs to Dance: Organizational Change } \\
\text { in Transition Economies ed. Daniel Denison. }\end{array}$ & & \\
\hline $\begin{array}{l}\text { No. 196: Understanding and Managing } \\
\text { Challenges to the Romanian Companies } \\
\text { during Transition. Forthcoming in Teaching } \\
\text { the Dinosaurs to Dance: Organizational } \\
\text { Change in Transition Economies ed. Daniel } \\
\text { Denison. }\end{array}$ & Dan Candea and Rodica M. Candea & January 1998 \\
\hline $\begin{array}{l}\text { No. 195: Insider Lending and Economic } \\
\text { Transition: The Structure, Function, and } \\
\text { Performance Impact of Finance Companies in } \\
\text { Chinese Business Groups. Forthcoming in } \\
\text { Teaching the Dinosaurs to Dance: } \\
\text { Organizational Change in Transition } \\
\text { Economies ed. Daniel Denison. }\end{array}$ & Lisa A. Keister & December 1997 \\
\hline $\begin{array}{l}\text { No. 194: Japanese Investment in Transitional } \\
\text { Economies: Characteristics and Performance. } \\
\text { Forthcoming in Teaching the Dinosaurs to } \\
\text { Dance: Organizational Change in Transition } \\
\text { Economies ed. Daniel Denison. }\end{array}$ & Paul W. Beamish and Andrew Delios & November 1997 \\
\hline $\begin{array}{l}\text { No. 193: Building Successful Companies in } \\
\text { Transition Economies. Forthcoming in } \\
\text { Teaching the Dinosaurs to Dance: } \\
\text { Organizational Change in Transition } \\
\text { Economies ed. Daniel Denison. }\end{array}$ & Dr. Ivan Perlaki & January 1998 \\
\hline $\begin{array}{l}\text { No. 192: Russian Communitariansim: An } \\
\text { Invisible Fist in the Transformation Process of } \\
\text { Russia. Forthcoming in Teaching the } \\
\text { Dinosaurs to Dance: Organizational Change } \\
\text { in Transition Economies ed. Daniel Denison. }\end{array}$ & Charalambos Vlachoutsicos & July 1998 \\
\hline No. 191: Teaching the Dinosaurs to Dance & Michal Cakrt & September 1997 \\
\hline $\begin{array}{l}\text { No. 190: Strategic Restructuring: Making } \\
\text { Capitalism in Post-Communist Eastern } \\
\text { Europe. Forthcoming in Teaching the } \\
\text { Dinosaurs to Dance: Organizational Change } \\
\text { in Transition Economies ed. Daniel Denison. }\end{array}$ & Lawrence P. King & September 1997 \\
\hline $\begin{array}{l}\text { No. 189: Published in: Regional Science and } \\
\text { Urban Economics, "Russia's Internal } \\
\text { Border", 29 (5), September 1999. }\end{array}$ & Daniel Berkowitz and David N. DeJong & July 1998 \\
\hline $\begin{array}{l}\text { No. 187: Corporate Structure and } \\
\text { Performance in Hungary }\end{array}$ & László Halpern and Gábor Kórsöi & July 1998 \\
\hline $\begin{array}{l}\text { No. 186: Performance of Czech Companies by } \\
\text { Ownership Structure }\end{array}$ & Andrew Weiss and Georgiy Nikitin & June 1998 \\
\hline $\begin{array}{l}\text { No. 185: Firm Performance in Bulgaria and } \\
\text { Estonia: The effects of competitive pressure, } \\
\text { financial pressure and disorganisation }\end{array}$ & Jozef Konings & July 1998 \\
\hline $\begin{array}{l}\text { No. 184: Investment and Wages during the } \\
\text { Transition: Evidence from Slovene Firms }\end{array}$ & Janez Prasnikar and Jan Svejnar & July 1998 \\
\hline No. 183: Investment Portfolio under Soft & Chongen Bai and Yijiang Wang & July 1998 \\
\hline
\end{tabular}

Working Papers are available at:

www.wdi.bus.umich.edu 


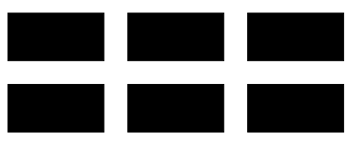

THE WILLIAM DAVIDSON INSTITUTE AT THE UNIVERSITY OF MICHIGAN BUSINESSSCHOOL

\begin{tabular}{|c|c|c|}
\hline $\begin{array}{l}\text { Budget: Implications for Growth, Volatility } \\
\text { and Savings }\end{array}$ & & \\
\hline $\begin{array}{l}\text { No. 181: Delegation and Delay in Bank } \\
\text { Privatization }\end{array}$ & Loránd Ambrus-Lakatos and Ulrich Hege & July 1998 \\
\hline $\begin{array}{l}\text { No. 180: Financing Mechanisms and } R \& D \\
\text { Investment }\end{array}$ & Haizhou Huang and Chenggang Xu & July 1998 \\
\hline $\begin{array}{l}\text { No. 179: Organizational Culture and } \\
\text { Effectiveness: The Case of Foreign Firms in } \\
\text { Russia }\end{array}$ & Carl F. Fey and Daniel R. Denison & January 1999 \\
\hline $\begin{array}{l}\text { No. 178: Output and Unemployment } \\
\text { Dynamics in Transition }\end{array}$ & Vivek H. Dehejia and Douglas W. Dwyer & January 1998 \\
\hline $\begin{array}{l}\text { No. 177: Published in: Economics of } \\
\text { Transition,, "Bureaucracies in the Russian } \\
\text { Voucher Privatization" Vol. } 8 \text {, No. 1, 2000, } \\
\text { pp. 37-57. }\end{array}$ & Guido Friebel & June 1998 \\
\hline $\begin{array}{l}\text { No. 176: Chronic Moderate Inflation in } \\
\text { Transition: The Tale of Hungary }\end{array}$ & János Vincze & June 1998 \\
\hline $\begin{array}{l}\text { No. 175: Privatisation and Market Structure } \\
\text { in a Transition Economy }\end{array}$ & John Bennett and James Maw & June 1998 \\
\hline $\begin{array}{l}\text { No. 174: Ownership and Managerial } \\
\text { Competition: Employee, Customer, or Outside } \\
\text { Ownership }\end{array}$ & Patrick Bolton and Chenggang $X u$ & June 1998 \\
\hline $\begin{array}{l}\text { No. 173: Intragovernment Procurement of } \\
\text { Local Public Good: A Theory of } \\
\text { Decentralization in Nondemocratic } \\
\text { Government }\end{array}$ & Chong-en Bai, Yu Pan and Yijiang Wang & June 1998 \\
\hline $\begin{array}{l}\text { No. 172: Political Instability and Growth in } \\
\text { Proprietary Economies }\end{array}$ & Jody Overland and Michael Spagat & August 1998 \\
\hline $\begin{array}{l}\text { No. 171: Published in Post-Communist } \\
\text { Economies, "Framework Issues in the } \\
\text { Privatization Strategies of the Czech Republic, } \\
\text { Hungary, and Poland" Vol. 11, no. 1 March } \\
\text { 1999. }\end{array}$ & Morris Bornstein & June 1998 \\
\hline $\begin{array}{l}\text { No. 170: Published in: European Journal of } \\
\text { Political Economy "Privatization, Ownership } \\
\text { Structure and Transparency: How to Measure } \\
\text { a Real Involvement of the State" 15(4), } \\
\text { November 1999, pp. 605-18. }\end{array}$ & Frantisek Turnovec & May 1998 \\
\hline $\begin{array}{l}\text { No. } 169 \text { Published in: American Economic } \\
\text { Review, "Unemployment and the Social Safety } \\
\text { Net during Transitions to a Market Economy: } \\
\text { Evidence from Czech and Slovak Men." Vol. } \\
\text { 88, No. 5, Dec. 1998, pp. 1117-1142. }\end{array}$ & $\begin{array}{l}\text { John C. Ham, Jan Svejnar, and Katherine } \\
\text { Terrell }\end{array}$ & December 1998 \\
\hline $\begin{array}{l}\text { No. 167: Voucher Privatization with } \\
\text { Investment Funds: An Institutional Analysis }\end{array}$ & David Ellerman & March 1998 \\
\hline $\begin{array}{l}\text { No. 166: Published in: Marketing Issues in } \\
\text { Transitional Economies, "Value Priorities } \\
\text { and Consumer Behavior in a Transitional } \\
\text { Economy: The Case of South Africa” ed. } \\
\text { Rajeev Batra. }\end{array}$ & $\begin{array}{l}\text { Steven M. Burgess and Jan-Benedict E.M. } \\
\text { Steenkamp }\end{array}$ & August 1998 \\
\hline $\begin{array}{l}\text { No. 164: Finance and Investment in } \\
\text { Transition: Czech Enterprises, 1993-1994 }\end{array}$ & Ronald Anderson and Chantal Kegels & September 1997 \\
\hline
\end{tabular}

Working Papers are available at:

www.wdi.bus.umich.edu 


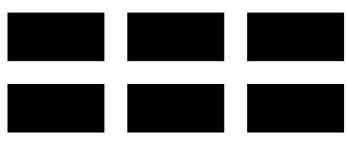

THE WILLIAM DAVIDSON INSTITUTE AT THE UNIVERSITY OF MICHIGAN BUSINESSSCHOOL

\begin{tabular}{|c|c|c|}
\hline $\begin{array}{l}\text { No. 163: European Union Trade and } \\
\text { Investment Flows U-Shaping Industrial } \\
\text { Output in Central and Eastern Europe: } \\
\text { Theory and Evidence }\end{array}$ & Alexander Repkine and Patrick P. Walsh & April 1998 \\
\hline $\begin{array}{l}\text { No. 162: Skill Acquisition and Private Firm } \\
\text { Creation in Transition Economies }\end{array}$ & Zuzana Brixiova and Wenli Li & October 1999 \\
\hline No. 161: Corruption in Transition & Susanto Basu and David D. Li & May 1998 \\
\hline $\begin{array}{l}\text { No. 160a: Tenures that Shook the World: } \\
\text { Worker Turnover in Russia, Poland and } \\
\text { Britain }\end{array}$ & $\begin{array}{l}\text { Hartmut Lehmann and Jonathan } \\
\text { Wadsworth }\end{array}$ & November 1999 \\
\hline $\begin{array}{l}\text { No. 160: Tenures that Shook the World: } \\
\text { Worker Turnover in the Russian Federation } \\
\text { and Poland }\end{array}$ & $\begin{array}{l}\text { Hartmut Lehmann and Jonathan } \\
\text { Wadsworth }\end{array}$ & June 1998 \\
\hline $\begin{array}{l}\text { No. 159: Does Market Structure Matter? New } \\
\text { Evidence from Russia }\end{array}$ & Annette N. Brown and J. David Brown & June 1998 \\
\hline $\begin{array}{l}\text { No. 158: Structural Adjustment and Regional } \\
\text { Long Term Unemployment in Poland }\end{array}$ & Hartmut Lehmann and Patrick P. Walsh & June 1997 \\
\hline $\begin{array}{l}\text { No. 157: Baby Boom or Bust? Changing } \\
\text { Fertility in Post-Communist Czech Republic } \\
\text { and Slovakia }\end{array}$ & Robert S. Chase & April 1998 \\
\hline $\begin{array}{l}\text { No. } 156 \text { Published in: Leadership and } \\
\text { Organization Development Journal, } \\
\text { "Leading Radical Change in Transition } \\
\text { Economies." Vol. 19, No. 6, 1998, pp. 309- } \\
324 .\end{array}$ & Karen L. Newman & June 1998 \\
\hline $\begin{array}{l}\text { No. } 155 \text { Published in: Oxford Review of } \\
\text { Economic Policy, "From Theory into } \\
\text { Practice? Restructuring and Dynamism in } \\
\text { Transition Economies." Vol. 13, No. 2, } \\
\text { Summer 1997, pp. } 77-105 .\end{array}$ & Wendy Carlin and Michael Landesmann & June 1997 \\
\hline $\begin{array}{l}\text { No. 154: The Model and the Reality: } \\
\text { Assessment of Vietnamese SOE Reform- } \\
\text { Implementation at the Firm Level }\end{array}$ & $\begin{array}{l}\text { Edmund Malesky, Vu Thanh Hung, Vu Thi } \\
\text { Dieu Anh, and Nancy K. Napier }\end{array}$ & July 1998 \\
\hline $\begin{array}{l}\text { No. } 153 \text { Published in: Journal of } \\
\text { Comparative Economics, "Causes of the Soft } \\
\text { Budget Constraint: Evidence on Three } \\
\text { Explanations." Vol. 26, No. 1, March 1998, } \\
\text { pp. 104-116. }\end{array}$ & David D. Li and Minsong Liang & March 1998 \\
\hline $\begin{array}{l}\text { No. } 152 \text { Published in: Comparative Economic } \\
\text { Studies, "Enterprise Restructuring in Russia's } \\
\text { Transition Economy: Formal and Informal } \\
\text { Mechanisms." Vol. 40, No. 2, Summer 1998, } \\
\text { pp. 5-52. }\end{array}$ & Susan J. Linz and Gary Krueger & April 1998 \\
\hline $\begin{array}{l}\text { No. 151: Labor Productivity in Transition: A } \\
\text { Regional Analysis of Russian Industry }\end{array}$ & Susan J. Linz & May 1998 \\
\hline $\begin{array}{l}\text { No. 150: Tax Avoidance and the Allocation of } \\
\text { Credit. Forthcoming in Financial Systems in } \\
\text { Transition: The Design of Financial Systems } \\
\text { in Central Europe eds. Anna Meyendorff and } \\
\text { Anjan Thakor. }\end{array}$ & Anna Meyendorff & June 1998 \\
\hline $\begin{array}{l}\text { No. 149: Commitment, Versatility and } \\
\text { Balance: Determinants of Work Time }\end{array}$ & Leslie Perlow and Ron Fortgang & April 1998 \\
\hline
\end{tabular}

Working Papers are available at: www.wdi.bus.umich.edu 


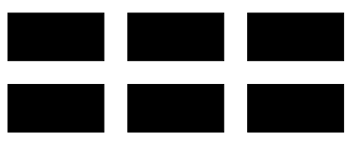

THE WILLIAM DAVIDSON INSTITUTE AT THE UNIVERSITY OF MICHIGAN BUSINESSSCHOOL

\begin{tabular}{|c|c|c|}
\hline $\begin{array}{l}\text { Standards and Norms in a Multi-Country } \\
\text { Study of Software Engineers }\end{array}$ & & \\
\hline $\begin{array}{l}\text { No. 148: Changes in Poland's Transfer } \\
\text { Payments in the 1990s: the Fate of } \\
\text { Pensioners }\end{array}$ & Bozena Leven & June 1998 \\
\hline $\begin{array}{l}\text { No. 147: Environmental Protection and } \\
\text { Economic Development: The Case of the } \\
\text { Huaihe River Basin Cleanup Plan }\end{array}$ & $\begin{array}{l}\text { Robert Letovsky, Reze Ramazani, and } \\
\text { Debra Murphy }\end{array}$ & June 1998 \\
\hline $\begin{array}{l}\text { No. 146: Chief Executive Compensation } \\
\text { During Early Transition: Further Evidence } \\
\text { from Bulgaria }\end{array}$ & $\begin{array}{l}\text { Derek C. Jones, Takao Kato, and Jeffrey } \\
\text { Miller }\end{array}$ & June 1998 \\
\hline $\begin{array}{l}\text { No. } 145 \text { Published in: Economics of } \\
\text { Transition, “Women's Unemployment During } \\
\text { the Transition: Evidence from Czech and } \\
\text { Slovak Micro Data," Vol. 7, No. 1, May 1999, } \\
\text { pp. 47-78. }\end{array}$ & $\begin{array}{l}\text { John Ham, Jan Svejnar, and Katherine } \\
\text { Terrell }\end{array}$ & May 1998 \\
\hline No. 144: Investment and Wages in Slovenia & Janez Prasnikar & May 1998 \\
\hline $\begin{array}{l}\text { No. } 143 \text { Published in: Review of Financial } \\
\text { Studies, "Optimal Bankruptcy Laws Across } \\
\text { Different Economic Systems," 12(2), Summer } \\
\text { 1999, pgs. 347-77. }\end{array}$ & Elazar Berkovitch and Ronen Israel & March 1998 \\
\hline $\begin{array}{l}\text { No. 142: Industrial Policy and Poverty in } \\
\text { Transition Economies: Two Steps Forward or } \\
\text { One Step Back? }\end{array}$ & Susan J. Linz & March 1998 \\
\hline $\begin{array}{l}\text { No. 141: Collective Ownership and } \\
\text { Privatization of China's Village Enterprises }\end{array}$ & Suwen Pan and Albert Park & April 1998 \\
\hline $\begin{array}{l}\text { No. 140: A Comparative Look at Labor } \\
\text { Mobility in the Czech Republic: Where have } \\
\text { all the Workers Gone? }\end{array}$ & Vit Sorm and Katherine Terrell & April 1999 \\
\hline $\begin{array}{l}\text { No. 139: The Failure of the Government-Led } \\
\text { Program of Corporate Reorganization in } \\
\text { Romania }\end{array}$ & Simeon Djankov and Kosali Ilayperuma & September 1997 \\
\hline $\begin{array}{l}\text { No. 138: Ownership and Employment in } \\
\text { Russian Industry: 1992-1995 }\end{array}$ & Susan J. Linz & March 1998 \\
\hline $\begin{array}{l}\text { No. } 137 \text { Published in: Journal of Political } \\
\text { Economy, “Reform Without Losers: An } \\
\text { Interpretation of China's Dual-Track } \\
\text { Approach to Transition," Feb. 2000; Vol. 108, } \\
\text { Iss.1; pg. } 120\end{array}$ & $\begin{array}{l}\text { Lawrence J. Lau, Yingyi Qian, and Gerard } \\
\text { Roland }\end{array}$ & November 1997 \\
\hline $\begin{array}{l}\text { No. } 136 \text { Published in: European Economic } \\
\text { Review, "The Political Economy of Mass } \\
\text { Privatization and the Risk of Expropriation," } \\
\text { 44(2), February 2000, pgs. 393-421 }\end{array}$ & Klaus M. Schmidt & March 1998 \\
\hline $\begin{array}{l}\text { No. 135: Radical Organizational Change: The } \\
\text { Role of Starting Conditions, Competition, and } \\
\text { Leaders }\end{array}$ & Karen L. Newman & January 1998 \\
\hline $\begin{array}{l}\text { No. 134: To Restructure or Not to } \\
\text { Restructure: Informal Activities and } \\
\text { Enterprise Behavior in Transition } \\
\text { No. 133: Management 101: Behavior of Firms } \\
\text { in Transition Economies }\end{array}$ & Clifford Gaddy and Barry W. Ickes & $\begin{array}{l}\text { May } 1998 \\
\text { March } 1998\end{array}$ \\
\hline No. 132 Published in: Quarterly Journal of & John McMillan and Christopher Woodruff & February 1998 \\
\hline
\end{tabular}

Working Papers are available at: www.wdi.bus.umich.edu 


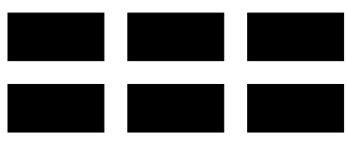

THE WILLIAM DAVIDSON INSTITUTE

AT THE UNIVERSITY OF MICHIGAN BUSINESSSCHOOL

\begin{tabular}{|c|c|c|}
\hline $\begin{array}{l}\text { Economics, “Interfirm Relationships and } \\
\text { Informal Credit in Vietnam," 114(4), Nov. } \\
\text { 1999, pgs. 1285-1320 }\end{array}$ & & \\
\hline $\begin{array}{l}\text { No. } 131 \text { Published in: Comparative Economic } \\
\text { Studies, “Will Restructuring Hungarian } \\
\text { Companies Innovate? An Investigation Based } \\
\text { on Joseph Berliner's Analysis of Innovation in } \\
\text { Soviet Industry.” Vol. 40, No. 2, Summer } \\
\text { 1998, pp. 53-74. }\end{array}$ & John B. Bonin and Istvan Abel & March 1998 \\
\hline $\begin{array}{l}\text { No. 130: Published in The American } \\
\text { Economic Review, "Changing Incentives of } \\
\text { the Chinese Bureaucracy." May, 1998. }\end{array}$ & David D. Li & January 1998 \\
\hline $\begin{array}{l}\text { No. 129: Restructuring Investment in } \\
\text { Transition: A Model of the Enterprise } \\
\text { Decision }\end{array}$ & Richard E. Ericson & January 1998 \\
\hline $\begin{array}{l}\text { No. } 128 \text { Published in: Comparative Economic } \\
\text { Studies, "Job Rights in Russian Firms: } \\
\text { Endangered or Extinct Institutions?" Vol. 40, } \\
\text { No. 4, Winter 1998, pp. 1-32. }\end{array}$ & Susan J. Linz & January 1998 \\
\hline $\begin{array}{l}\text { No. 127: Accounting for Growth in Post- } \\
\text { Soviet Russia }\end{array}$ & Daniel Berkowitz and David N. DeJong & January 1998 \\
\hline $\begin{array}{l}\text { No. } 126 \text { Published in: Economics of } \\
\text { Transition, "From Federalism, Chinese Style, } \\
\text { to Privatization Chinese Style," 7(1), 1999, } \\
\text { pgs. 103-31 }\end{array}$ & $\begin{array}{l}\text { Yuanzheng Cao, Yingyi Qian, and Barry R. } \\
\text { Weingast }\end{array}$ & December 1997 \\
\hline $\begin{array}{l}\text { No. 125: Market Discipline in Conglomerate } \\
\text { Banks: Is an Internal Allocation of Cost of } \\
\text { Capital Necessary as Incentive Device? } \\
\text { Forthcoming in Financial Systems in } \\
\text { Transition: The Design of Financial Systems } \\
\text { in Central Europe eds. Anna Meyendorff and } \\
\text { Anjan Thakor. }\end{array}$ & Arnoud W. A. Boot and Anjolein Schmeits & November 1997 \\
\hline $\begin{array}{l}\text { No. 124: Financial Discipline in the } \\
\text { Enterprise Sector in Transition Countries: } \\
\text { How Does China Compare? }\end{array}$ & Shumei Gao and Mark E. Schaffer & February 1998 \\
\hline $\begin{array}{l}\text { No. 123: Considerations of an Emerging } \\
\text { Marketplace: Managers' Perceptions in the } \\
\text { Southern African Economic Community }\end{array}$ & Brent Chrite and David Hudson & February 1998 \\
\hline $\begin{array}{l}\text { No. 122: A Model of the Informal Economy in } \\
\text { Transition Economies }\end{array}$ & $\begin{array}{l}\text { Simon Commander and Andrei } \\
\text { Tolstopiatenko }\end{array}$ & November 1997 \\
\hline $\begin{array}{l}\text { No. 121: Local Labour Market Dynamics in } \\
\text { the Czech and Slovak Republics }\end{array}$ & Peter Huber and Andreas Worgotter & November 1997 \\
\hline $\begin{array}{l}\text { No. 121: Local Labour Market Dynamics in } \\
\text { the Czech and Slovak Republics }\end{array}$ & Peter Huber and Andreas Worgotter & November 1997 \\
\hline $\begin{array}{l}\text { No. 119: Institutional Upheaval and Company } \\
\text { Transformation in Emerging Market } \\
\text { Economies }\end{array}$ & Karen L. Newman & March 1998 \\
\hline $\begin{array}{l}\text { No. 118: Industrial Decline and Labor } \\
\text { Reallocation in Romania }\end{array}$ & John S. Earle & October 1997 \\
\hline $\begin{array}{l}\text { No. 117: Notes for an Essay on the Soft } \\
\text { Budget Constraint }\end{array}$ & Lorand Ambrus-Lakatos & January 1997 \\
\hline No. 116: Labor Demand During Transition in & Gabor Korosi & October 1997 \\
\hline
\end{tabular}

Working Papers are available at:

www.wdi.bus.umich.edu 


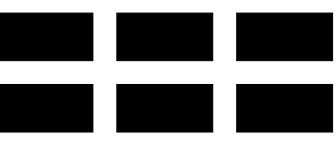

THE WILLIAM DAVIDSON INSTITUTE AT THE UNIVERSITY OF MICHIGAN BUSINESSSCHOOL

\begin{tabular}{|c|c|c|}
\hline Hungary & & \\
\hline $\begin{array}{l}\text { No. 115: Enterprise Performance and } \\
\text { Managers' Profiles }\end{array}$ & Simeon Djankov and Stijn Claessens & December 1997 \\
\hline $\begin{array}{l}\text { No. } 114 b \text { Employment and Wages in } \\
\text { Enterprises under Communism and in } \\
\text { Transition: Evidence From Central Europe } \\
\text { and Russia }\end{array}$ & Swati Basu, Saul Estrin, and Jan Svejnar & April 2000 \\
\hline $\begin{array}{l}\text { No. 114: Employment and Wage Behavior of } \\
\text { Enterprises in Transitional Economies }\end{array}$ & Swati Basu, Saul Estrin, and Jan Svejnar & October 1997 \\
\hline $\begin{array}{l}\text { No. 113: Preliminary Evidence on Active } \\
\text { Labor Programs' Impact in Hungary and } \\
\text { Poland }\end{array}$ & Christopher J. O’Leary & October 1997 \\
\hline $\begin{array}{l}\text { No. 111: Unemployment Benefits and } \\
\text { Incentives in Hungary: New Evidence }\end{array}$ & Joachim Wolff & October 1997 \\
\hline $\begin{array}{l}\text { No. 110: Published in: Empirical Economics, } \\
\text { "Long-Term Unemployment, Unemployment } \\
\text { Benefits and Social Assistance: The Polish } \\
\text { Experience" Empirical-Economics; 23(1-2), } \\
\text { 1998, pages 55-85. }\end{array}$ & Marek Gora and Christoph M. Schmidt & April 1997 \\
\hline $\begin{array}{l}\text { No. } 109 \text { Published in: Industrial and Labor } \\
\text { Relations Review, “Markets for Communist } \\
\text { Human Capital: Returns to Education and } \\
\text { Experience in Post-Communist Czech } \\
\text { Republic and Slovakia.” Vol. 51, No. 3, April } \\
\text { 1998, pp. 401-423. }\end{array}$ & Robert S. Chase & October 1997 \\
\hline $\begin{array}{l}\text { No. 107: The Worker-Firm Matching in the } \\
\text { Transition: (Why) Are the Czechs More } \\
\text { Successful Than Others? }\end{array}$ & $\begin{array}{l}\text { Daniel Münich, Jan Svejnar, and } \\
\text { Katherine Terrell }\end{array}$ & October 1997 \\
\hline $\begin{array}{l}\text { No. } 106 \text { Published in: Journal of } \\
\text { Comparative Economics, "Job Creation, Job } \\
\text { Destruction and Growth of Newly Established, } \\
\text { Privatized and State-Owned Enterprises in } \\
\text { Transition Economies: Survey Evidence from } \\
\text { Bulgaria, Hungary, and Romania," Vol. 26, } \\
\text { No.3, September 1998, pp. 429-445. }\end{array}$ & Valentijn Bilsen and Jozef Konings & September 1998 \\
\hline $\begin{array}{l}\text { No. 105: Getting Behind the East-West } \\
\text { [German] Wage Differential: Theory and } \\
\text { Evidence }\end{array}$ & Michael Burda and Christoph Schmidt & May 1997 \\
\hline $\begin{array}{l}\text { No. 104: The Birth of the "Wage Curve" in } \\
\text { Hungary, 1989-95 }\end{array}$ & Gabor Kertesi and Janos Kollo & October 1997 \\
\hline $\begin{array}{l}\text { No. 103: Published in: Journal of } \\
\text { Comparative Economics, "Grime and } \\
\text { Punishment: Job Insecurity and Wage Arrears } \\
\text { in the Russian Federation" 27, 595-617 } \\
\text { (1999). }\end{array}$ & $\begin{array}{l}\text { Hartmut Lehmann, Jonathan Wadsworth, } \\
\text { and Alessandro Acquisti }\end{array}$ & October 1997 \\
\hline No. 102: Social Networks in Transition & $\begin{array}{l}\text { Lorena Barberia, Simon Johnson, and } \\
\text { Daniel Kaufmann }\end{array}$ & October 1997 \\
\hline $\begin{array}{l}\text { No. 101: Depreciation and Russian Corporate } \\
\text { Finance: A Pragmatic Approach to Surviving } \\
\text { the Transition }\end{array}$ & Susan J. Linz & November 1997 \\
\hline No. 100: Romanian Financial System Reform & Anna Meyendorff and Anjan V. Thakor & November 1997 \\
\hline No. 99: Proceedings of the Conference on & Edited by Cynthia Koch & May 1997 \\
\hline
\end{tabular}

Working Papers are available at:

www.wdi.bus.umich.edu 


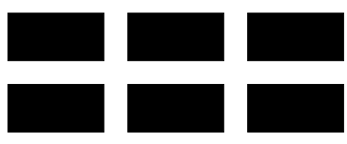

THE WILLIAM DAVIDSON INSTITUTE

AT THE UNIVERSITY OF MICHIGAN BUSINESSSCHOOL

\begin{tabular}{|c|c|c|}
\hline $\begin{array}{l}\text { Strategic Alliances in Transitional Economies, } \\
\text { held May 20, } 1997 \text { at the Davidson Institute }\end{array}$ & & \\
\hline $\begin{array}{l}\text { No. 98: Institutions, Strain and the } \\
\text { Underground Economy }\end{array}$ & Daniel Daianu and Lucian Albu & November 1997 \\
\hline $\begin{array}{l}\text { No. 97: Structure and Strain in Explaining } \\
\text { Inter-Enterprise Arrears }\end{array}$ & Daniel Daianu & November 1997 \\
\hline $\begin{array}{l}\text { No. 96: Resource Misallocation and Strain: } \\
\text { Explaining Shocks in Post-Command } \\
\text { Economies }\end{array}$ & Daniel Daianu & November 1997 \\
\hline $\begin{array}{l}\text { No. 95: Published in: Finance-a-Uver, } \\
\text { "Czech Money Market: Emerging Links } \\
\text { Among Interest Rates." 48(2) } 1998 \text { pp. 99- } \\
\text { 109. }\end{array}$ & Jan Hanousek and Evzen Kocenda & November 1997 \\
\hline $\begin{array}{l}\text { No. 94: Pre-Reform Industry and the } \\
\text { State Monopsony in China }\end{array}$ & Xiao-Yuan Dong and Louis Putterman & October 1997 \\
\hline $\begin{array}{l}\text { No. 93: China's State-Owned Enterprises } \\
\text { In the First Reform Decade: } \\
\text { An Analysis of a Declining Monopsony }\end{array}$ & Xiao-Yuan Dong and Louis Putterman & October 1997 \\
\hline $\begin{array}{l}\text { No. 92: Expatriate Management in the Czech } \\
\text { Republic }\end{array}$ & Richard B. Peterson & September 1997 \\
\hline $\begin{array}{l}\text { No. 91: China and the Idea of Economic } \\
\text { Reform }\end{array}$ & Thomas G. Rawski & April 1997 \\
\hline $\begin{array}{l}\text { No. } 90 \text { Published in: China Economic } \\
\text { Review, "China's State Enterprise Reform: An } \\
\text { Overseas Perspective." Vol. 8, Spring 1997, } \\
\text { pp. 89-98. }\end{array}$ & Thomas G. Rawski & July 1997 \\
\hline $\begin{array}{l}\text { No. 89: The Economic Determinants of } \\
\text { Internal Migration Flows in Russia During } \\
\text { Transition }\end{array}$ & Annette N. Brown & July 1997 \\
\hline $\begin{array}{l}\text { No. 88: Gender Wage Gaps in China's Labor } \\
\text { Market: Size, Structure, Trends }\end{array}$ & $\begin{array}{l}\text { Margaret Maurer-Fazio, Thomas G. } \\
\text { Rawski, and Wei Zhang }\end{array}$ & July 1997 \\
\hline $\begin{array}{l}\text { No. 87: Privatisation in Central and Eastern } \\
\text { Europe }\end{array}$ & Saul Estrin & June 1997 \\
\hline $\begin{array}{l}\text { No. 86: Published in : Economics of } \\
\text { Transition, "The Effect of Privatization on } \\
\text { Wealth Distribution in Russia." v. 7, no. 2, } \\
\text { 1999, pp. 449-65 }\end{array}$ & Michael Alexeev & February 1998 \\
\hline $\begin{array}{l}\text { No. 85: Was Privatization in Eastern Germany } \\
\text { a Special Case? Some Lessons from the } \\
\text { Treuhand }\end{array}$ & Uwe Siegmund & September 1997 \\
\hline No. 84: Start-ups and Transition & Daniel M. Berkowitz and David J. Cooper & September 1997 \\
\hline $\begin{array}{l}\text { No. 83: Which Enterprises (Believe They) } \\
\text { Have Soft Budgets after Mass Privatization? } \\
\text { Evidence from Mongolia }\end{array}$ & $\begin{array}{l}\text { James Anderson, Georges Korsun, and } \\
\text { Peter Murrell }\end{array}$ & October 1997 \\
\hline $\begin{array}{l}\text { No. 82: Published in: European Economic } \\
\text { Review, "Unemployment Dynamics and the } \\
\text { Restructuring of the Slovak Unemployment } \\
\text { Benefit System." April, 1997. }\end{array}$ & Martina Lubyova and Jan C. van Ours & June 1997 \\
\hline $\begin{array}{l}\text { No. 81: Determinants of Unemployment } \\
\text { Duration in Russia }\end{array}$ & Mark C. Foley & August 1997 \\
\hline $\begin{array}{l}\text { No. 80: The Many Faces of Information } \\
\text { Disclosure }\end{array}$ & Arnoud W.A. Boot and Anjan V. Thakor & October 1997 \\
\hline
\end{tabular}

Working Papers are available at:

www.wdi.bus.umich.edu 


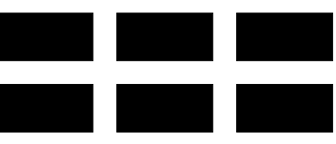

THE WILLIAM DAVIDSON INSTITUTE

AT THE UNIVERSITY OF MICHIGAN BUSINESSSCHOOL

\begin{tabular}{|c|c|c|}
\hline $\begin{array}{l}\text { No. 79: Published in: Journal of Finance, } \\
\text { "Foreign Speculators and Emerging Equity } \\
\text { Markets."v.22, iss. 2, 2000, pp. 565-613 }\end{array}$ & Geert Bekaert and Campbell R. Harvey & August 1997 \\
\hline $\begin{array}{l}\text { No. 78: The Relationship Between Economic } \\
\text { Factors and Equity Markets in Central Europe }\end{array}$ & Jan Hanousek and Randall K. Filer & June 1997 \\
\hline $\begin{array}{l}\text { No. } 77 \text { Published in: Economics of } \\
\text { Transition, "A Gini Decomposition Analysis } \\
\text { of Inequality in the Czech and Slovak } \\
\text { Republics During the Transition," Vol. 6, } \\
\text { No.1, May 1998, pp. 23-46. }\end{array}$ & Thesia I. Garner and Katherine Terrell & May 1998 \\
\hline $\begin{array}{l}\text { No. 76: China's Emerging Market for } \\
\text { Property Rights: Theoretical and Empirical } \\
\text { Perspectives }\end{array}$ & Gary H. Jefferson and Thomas G. Rawski & June 1997 \\
\hline $\begin{array}{l}\text { No. } 75 b: \text { Test of Permanent Income } \\
\text { Hypothesis on Czech Voucher Privatization }\end{array}$ & Jan Hanousek and Zdenek Tima & October 1997 \\
\hline $\begin{array}{l}\text { No. 74: Determinants of Performance of } \\
\text { Manufacturing Firms in Seven European } \\
\text { Transition Economies }\end{array}$ & $\begin{array}{l}\text { Stijn Claessens, Simeon Djankov, and } \\
\text { Gerhard Pohl }\end{array}$ & February 1997 \\
\hline $\begin{array}{l}\text { No. } 73 \text { Published in: Economics of } \\
\text { Transition, "The Restructuring of Large } \\
\text { Firms in Slovak Republic." Vol. 6, No. 1, May } \\
\text { 1998, pp. 67-85 }\end{array}$ & Simeon Djankov and Gerhard Pohl & May 1998 \\
\hline $\begin{array}{l}\text { No. 72: Law, Relationships, and Private } \\
\text { Enforcement: Transactional Strategies of } \\
\text { Russian Enterprises }\end{array}$ & $\begin{array}{l}\text { Kathryn Hendley, Peter Murrell, and } \\
\text { Randi Ryterman }\end{array}$ & November 1998 \\
\hline $\begin{array}{l}\text { No. 71: Giving Credit Where Credit Is Due: } \\
\text { The Changing Role of Rural Financial } \\
\text { Institutions in China }\end{array}$ & Albert Park, Loren Brandt, and John Giles & March 1997 \\
\hline $\begin{array}{l}\text { No. 70: Privatization Versus Competition: } \\
\text { Changing Enterprise Behavior in Russia }\end{array}$ & John S. Earle and Saul Estrin & Spring 1997 \\
\hline $\begin{array}{l}\text { No. 69: Russian Managers under Storm: } \\
\text { Explicit Reality and Implicit Leadership } \\
\text { Theories (A Pilot Exploration) }\end{array}$ & Igor Gurkov & October 1998 \\
\hline $\begin{array}{l}\text { No. 68: The Political Economy of Central- } \\
\text { Local Relations in China: Inflation and } \\
\text { Investment Controls During the Reform Era }\end{array}$ & Yasheng Huang & Spring 1997 \\
\hline $\begin{array}{l}\text { No. 67: Between Two Coordination Failures: } \\
\text { Automotive Industrial Policy in China with a } \\
\text { Comparison to Korea }\end{array}$ & Yasheng Huang & Spring 1997 \\
\hline $\begin{array}{l}\text { No. } 66 \text { Published in: Post-Soviet Geography } \\
\text { and Economics, "Red Executives in Russia's } \\
\text { Transition Economy." Vol. 27, No. 10, } \\
\text { November 1996, pp. 633-651. }\end{array}$ & Susan J. Linz & January 1997 \\
\hline $\begin{array}{l}\text { No. } 65 \text { Published in: Industrial and } \\
\text { Corporate Change, "On the Sequencing of } \\
\text { Privatization in Transition Economies." Vol. } \\
\text { 7, No. 1, 1998. }\end{array}$ & Gautam Ahuja and Sumit K. Majumdar & April 1997 \\
\hline $\begin{array}{l}\text { No. 64: Published in: Journal of Law and } \\
\text { Economics, "Foreign Ownership and } \\
\text { Profitability: Property Rights, Control and the } \\
\text { Performance of Firms in Indian Industry" } \\
\text { 42(1), April 1999, pp. 209-38. }\end{array}$ & $\begin{array}{l}\text { Pradeep K. Chhibber and Sumit K. } \\
\text { Majumdar }\end{array}$ & April 1997 \\
\hline
\end{tabular}

Working Papers are available at:

www.wdi.bus.umich.edu 


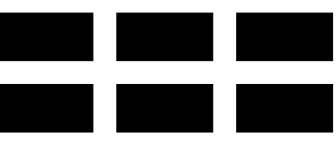

THE WILLIAM DAVIDSON INSTITUTE AT THE UNIVERSITY OF MICHIGAN BUSINESSSCHOOL

\begin{tabular}{|c|c|c|}
\hline $\begin{array}{l}\text { No. 63: How Taxing Is Corruption on } \\
\text { International Investors? }\end{array}$ & Shang-Jin Wei & February 1997 \\
\hline $\begin{array}{l}\text { No. 62: What Can We Learn from the } \\
\text { Experience of Transitional Economies with } \\
\text { Labour Market Policies? }\end{array}$ & Tito Boeri & 1997 \\
\hline $\begin{array}{l}\text { No. 61: Published in: Accounting } \\
\text { Organizations and Society, "Economic } \\
\text { Transition, Strategy and the Evolution of } \\
\text { Management Accounting Practices: The Case } \\
\text { of India" 24(5,6), Jul/Aug 1999, pp. 379-412. }\end{array}$ & $\begin{array}{l}\text { Shannon W. Anderson and William N. } \\
\text { Lanen }\end{array}$ & April 1997 \\
\hline $\begin{array}{l}\text { No. 60a: Enterprise Investment During the } \\
\text { Transition: Evidence from Czech Panel Data }\end{array}$ & Lubomír Lizal and Jan Svejnar & December 1997 \\
\hline $\begin{array}{l}\text { No. 59: Published in: Journal of Law, } \\
\text { Economics, and Organization, "Institutional } \\
\text { Environment, Community Government, and } \\
\text { Corporate Governance: Understanding } \\
\text { China's Township-Village Enterprises." } \\
\text { 14(1), April 1998, pages 1-23 }\end{array}$ & Jiahua Che and Yingyi Qian & April 1997 \\
\hline $\begin{array}{l}\text { No. 58: From the Grabbing Hand to the } \\
\text { Helping Hand }\end{array}$ & Jiahua Che & June 2000 \\
\hline $\begin{array}{l}\text { No. 57: Published in: Brookings Papers on } \\
\text { Economic Activity, "The Unofficial Economy } \\
\text { in Transition." 1: 1998. }\end{array}$ & $\begin{array}{l}\text { Simon Johnson, Daniel Kaufmann, and } \\
\text { Andrei Schleifer }\end{array}$ & June 1997 \\
\hline $\begin{array}{l}\text { No. 56: Taxes and Government Incentives: } \\
\text { Eastern Europe vs. China }\end{array}$ & Roger H. Gordon and David D. Li & April 1997 \\
\hline No. 55: Corruption and Reform & Susanto Basu and David Li & June 1996 \\
\hline $\begin{array}{l}\text { No. 54: Decentralization and the } \\
\text { Macroeconomic Consequences of } \\
\text { Commitment to State-Owned Firms }\end{array}$ & Loren Brandt and Xiaodong Zhu & June 1997 \\
\hline $\begin{array}{l}\text { No. 53: Published in: The International } \\
\text { Journal of Industrial Organization, } \\
\text { "Competitive Shocks and Industrial Structure: } \\
\text { The Case of Polish Manufacturing." August, } \\
\text { 1999. . }\end{array}$ & Pankaj Ghemawat and Robert E. Kennedy & May 1997 \\
\hline $\begin{array}{l}\text { No. 52: Published in: The Quarterly Journal } \\
\text { of Economics, "Insecure Property Rights and } \\
\text { Government Ownership of Firms." May, } \\
\text { 1998. }\end{array}$ & Jiahua Che and Yingyi Qian & May 1997 \\
\hline $\begin{array}{l}\text { No. 51: Incentives, Scale Economies, and } \\
\text { Organizational Form }\end{array}$ & $\begin{array}{l}\text { Eric Maskin, Yingyi Qian, and Chenggang } \\
X u\end{array}$ & May 1997 \\
\hline $\begin{array}{l}\text { No. 50: Published in: Post-Soviet-Affairs, } \\
\text { "End of the Tunnel? The Effects of Financial } \\
\text { Stabilization in Russia" April-June 1997, } \\
\text { pages 105-33 }\end{array}$ & $\begin{array}{l}\text { Barry W. Ickes, Peter Murrell, and Randi } \\
\text { Ryterman }\end{array}$ & March 1997 \\
\hline $\begin{array}{l}\text { No. 49: The Evolution of Bank Credit Quality } \\
\text { in Transition: Theory and Evidence from } \\
\text { Romania }\end{array}$ & Enrico C. Perotti and Octavian Carare & October 1996 \\
\hline $\begin{array}{l}\text { No. 48: Where Do the Leaders Trade? } \\
\text { Information Revelation and Interactions } \\
\text { Between the Segments of Czech Capital } \\
\text { Markets }\end{array}$ & Jan Hanousek and Libor Nemecek & May 1997 \\
\hline No. 47: Firms' Heterogeneity in Transition: & Irena Grosfeld and Jean-François Nivet & May 1997 \\
\hline
\end{tabular}

Working Papers are available at:

www.wdi.bus.umich.edu 


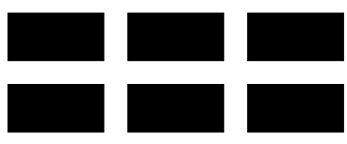

THE WILLIAM DAVIDSON INSTITUTE

AT THE UNIVERSITY OF MICHIGAN BUSINESSSCHOOL

\begin{tabular}{|c|c|c|}
\hline Evidence from a Polish Panel Data Set & & \\
\hline $\begin{array}{l}\text { No. 46: Strategic Creditor Passivity, } \\
\text { Regulation, and Bank Bailouts }\end{array}$ & Janet Mitchell & May 1997 \\
\hline $\begin{array}{l}\text { No. 45a: Published in: Journal of Public } \\
\text { Economics, "Tax Rights in Transition } \\
\text { Economies: A Tragedy of the Commons." } 76 \text {, } \\
\text { 2000, pp. 369-397 }\end{array}$ & Daniel M. Berkowitz and Wei Li & September 1997 \\
\hline $\begin{array}{l}\text { No. 44a: The Information Content of Stock } \\
\text { Markets: Why do Emerging Markets have } \\
\text { Synchronous Stock Price Movements? } \\
\text { (forthcoming in the Journal of Financial } \\
\text { Economics). }\end{array}$ & $\begin{array}{l}\text { Randall Morck, Bernard Yeung, and } \\
\text { Wayne Yu }\end{array}$ & February 1999 \\
\hline $\begin{array}{l}\text { No. 43: Agency in Project Screening and } \\
\text { Termination Decisions: Why Is Good Money } \\
\text { Thrown After Bad? }\end{array}$ & Chong-en Bai and Yijiang Wang & May 1997 \\
\hline $\begin{array}{l}\text { No. 42: Published in: Economics of } \\
\text { Transition, "Channels of Redistribution: } \\
\text { Inequality and Poverty in the Russian } \\
\text { Transition." Vol. } 7 \text { (2) } 1999 .\end{array}$ & $\begin{array}{l}\text { Simon Commander, Andrei Tolstopiatenko, } \\
\text { and Ruslan Yemtsov }\end{array}$ & May 1997 \\
\hline $\begin{array}{l}\text { No. 41: Published in: Economics of } \\
\text { Transition, "Labour Market Characteristics } \\
\text { and Profitability: Econometric Analysis of } \\
\text { Hungarian Exporting Firms, 1986-1995" } \\
\text { 6(1), May 1998, pages 145-62 }\end{array}$ & László Halpern and Gabor Korosi & May 1997 \\
\hline $\begin{array}{l}\text { No. 40: Published in: the Harvard Law } \\
\text { Review, "The Tragedy of the Anticommons: } \\
\text { Property in the Transition from Marx to } \\
\text { Markets." January } 1998 .\end{array}$ & Michael Heller & February 1997 \\
\hline $\begin{array}{l}\text { No. 39: Privatization and Managerial } \\
\text { Efficiency }\end{array}$ & Olivier Debande and Guido Friebel & May 1997 \\
\hline $\begin{array}{l}\text { No. } 38 \text { Published in: The Quarterly Journal } \\
\text { of Economics, “Disorganization.” Vol. 112, } \\
\text { No. 4, November 1997, pp. 1091-1126. }\end{array}$ & Olivier Blanchard and Michael Kremer & January 1997 \\
\hline $\begin{array}{l}\text { No. 37: Published in: Economics of } \\
\text { Transition, "Transition and the Output Fall." } \\
\text { 7(1), 1999, pages 1-28. }\end{array}$ & Gérard Roland and Thierry Verdier & March 1997 \\
\hline $\begin{array}{l}\text { No. 36: Restructuring an Industry During } \\
\text { Transition: A Two-Period Model }\end{array}$ & Richard Ericson & September 1996 \\
\hline $\begin{array}{l}\text { No. 34: The East-West Joint Venture: BC } \\
\text { Torsion Case Study }\end{array}$ & Sonia Ferencikova and Vern Terpstra & December 1998 \\
\hline $\begin{array}{l}\text { No. } 33 \text { Published in: Journal of Comparative } \\
\text { Economics, "Quantifying Price Liberalization } \\
\text { in Russia." Vol. 26, No. 4, December 1998, } \\
\text { pp. } 735-737 .\end{array}$ & $\begin{array}{l}\text { Daniel Berkowitz, David DeJong, and } \\
\text { Steven Husted }\end{array}$ & December 1998 \\
\hline $\begin{array}{l}\text { No. 32: What Can North Korea Learn from } \\
\text { China's Market Reforms? }\end{array}$ & John McMillan & September 1996 \\
\hline $\begin{array}{l}\text { No. 31: Published in: China-Economic- } \\
\text { Review, "Towards a Model of China as a } \\
\text { Partially Reformed Developing Economy } \\
\text { Under a Semifederalist Government.", 9(1), } \\
\text { Spring 1998, pages 1-23. }\end{array}$ & Yijiang Wang and Chun Chang & March 1997 \\
\hline No. 30: Convergence in Output in Transition & Saul Estrin and Giovanni Urga & February 1997 \\
\hline
\end{tabular}

Working Papers are available at:

www.wdi.bus.umich.edu 


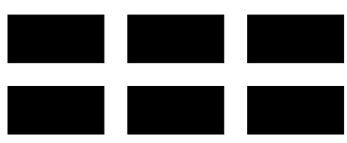

THE WILLIAM DAVIDSON INSTITUTE

AT THE UNIVERSITY OF MICHIGAN BUSINESSSCHOOL

\begin{tabular}{|c|c|c|}
\hline $\begin{array}{l}\text { Economies: Central and Eastern Europe, } \\
\text { 1970-1995 }\end{array}$ & & \\
\hline $\begin{array}{l}\text { No. 29: Published in: Economics of } \\
\text { Transition, "Altered Band and Exchange } \\
\text { Volatility." Volume 6, no. 1, 1998, 173-181. }\end{array}$ & Evzen Kocenda & March 1997 \\
\hline $\begin{array}{l}\text { No. 28: Published in: Quarterly Journal of } \\
\text { Economics, "Public Versus Private } \\
\text { Ownership of Firms: Evidence from Rural } \\
\text { China." Volume 113, no. 3, August 1998, } 773 \text { - } \\
\text { 808. }\end{array}$ & Hehui Jin and Yingyi Qian & January 1997 \\
\hline $\begin{array}{l}\text { No. 27: East-West Joint Ventures in a } \\
\text { Transitional Economy: The Case of Slovakia }\end{array}$ & Sonia Ferencikova & March 1997 \\
\hline $\begin{array}{l}\text { No. 26: Published in Economic Analysis } \\
\text { "Behavior of a Slovenian Firm in Transition", } \\
\text { Vol. 1, no. 1, 1998, 57-73. }\end{array}$ & Janez Prasnikar & February 1997 \\
\hline $\begin{array}{l}\text { No. 25: Cultural Encounters and Claims to } \\
\text { Expertise in Postcommunist Capitalism }\end{array}$ & Michael D. Kennedy & February 1997 \\
\hline $\begin{array}{l}\text { No. 24: ZVU a.s.: Investment Funds on the } \\
\text { Board of Directors of an Engineering Giant }\end{array}$ & Tory Wolff & August 1995 \\
\hline $\begin{array}{l}\text { No. 23: The Role of Investment Funds in the } \\
\text { Czech Republic (joint publication with Czech } \\
\text { Management Center) }\end{array}$ & Dusan Triska & June 1996 \\
\hline $\begin{array}{l}\text { No. 22: Czech Investment Fund Industry: } \\
\text { Development and Behaviour (joint publication } \\
\text { with Czech Management Center) }\end{array}$ & Richard Podpiera & May 1996 \\
\hline $\begin{array}{l}\text { No. 21: Restructuring of Czech Firms: An } \\
\text { Example of Gama, a.s. (joint publication with } \\
\text { Czech Management Center) }\end{array}$ & Antonin Bulin & June 1996 \\
\hline $\begin{array}{l}\text { No. 20: YSE Funds: A Story of Czech } \\
\text { Investment Funds (joint publication with } \\
\text { Czech Management Center) }\end{array}$ & Michal Otradovec & November 1995 \\
\hline $\begin{array}{l}\text { No. 19: Prvni Investicni a.s., The First } \\
\text { Investment Corporation (joint publication } \\
\text { with Czech Management Center) }\end{array}$ & Jaroslav Jirasek & August 1995 \\
\hline $\begin{array}{l}\text { No. 18: PPF a.s., The First Private Investment } \\
\text { Fund (joint publication with Czech } \\
\text { Management Center) }\end{array}$ & Michal Otradovec & November 1995 \\
\hline $\begin{array}{l}\text { No. } 17 \text { Published in: Post-Soviet Geography } \\
\text { and Economics, "Russia's Managers in } \\
\text { Transition: Pilferers or Paladins?" Vol. 37, } \\
\text { o.7 (September 1996), pp. 397-426. }\end{array}$ & Susan J. Linz and Gary Krueger & November 1996 \\
\hline $\begin{array}{l}\text { No. 16: Banks in Transition-Investment } \\
\text { Opportunities in Central Europe and Russia } \\
\text { Edited Transcript from } 31 \text { May } 1996 \\
\text { Conference in New York City }\end{array}$ & $\begin{array}{l}\text { With commentary and edited by Anna } \\
\text { Meyendorff }\end{array}$ & January 1997 \\
\hline $\begin{array}{l}\text { No. 15: Marketing in Transitional Economies: } \\
\text { Edited Transcript \& Papers from } 1 \text { April } 1996 \\
\text { Conference in Ann Arbor, Michigan }\end{array}$ & Compiled by The Davidson Institute & December 1996 \\
\hline $\begin{array}{l}\text { No. 14: Pensions in the Former Soviet Bloc: } \\
\text { Problems and Solutions. Published by } \\
\text { Council on Foreign Relations. "The Coming } \\
\text { Global Pension Crisis" New York, } 1997\end{array}$ & Jan Svejnar & November 1996 \\
\hline
\end{tabular}

Working Papers are available at:

www.wdi.bus.umich.edu 


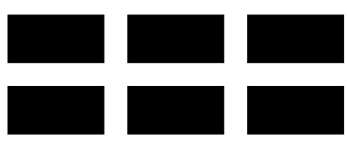

THE WILLIAM DAVIDSON INSTITUTE

AT THE UNIVERSITY OF MICHIGAN BUSINESSSCHOOL

\begin{tabular}{|c|c|c|}
\hline $\begin{array}{l}\text { No. 13: Enterprise Restructuring and } \\
\text { Performance in the Transition. Forthcoming } \\
\text { in Financial Systems in Transition: The } \\
\text { Design of Financial Systems in Central } \\
\text { Europe eds. Anna Meyendorff and Anjan } \\
\text { Thakor. }\end{array}$ & $\begin{array}{l}\text { Lubomir Lizal, Miroslav Singer, and Jan } \\
\text { Svejnar }\end{array}$ & December 1996 \\
\hline $\begin{array}{l}\text { No. } 12 \text { Published in: Journal of International } \\
\text { Marketing, "Executive Insights: Marketing } \\
\text { Issues and Challenges in Transitional } \\
\text { Economies." Vol. 5, No. 4, 1997, pp. 95-114. } \\
\text { Also published in: Marketing Issues in } \\
\text { Transitional Economies ed. Rajeev Batra. }\end{array}$ & Rajeev Batra & April 1997 \\
\hline $\begin{array}{l}\text { No. 11: Worker Trust and System } \\
\text { Vulnerability in the Transition from Socialism } \\
\text { to Capitalism }\end{array}$ & Andrew Schotter & August 1996 \\
\hline $\begin{array}{l}\text { No. } 10 \text { Published in: Comparative Economic } \\
\text { Studies, "Russian Firms in Transition: } \\
\text { Champions, Challengers, and Chaff." Vol. } \\
\text { 39, No.2, Summer 1997, pp. 1-36. }\end{array}$ & Susan J. Linz & July 1996 \\
\hline $\begin{array}{l}\text { No. 9: Corporate Debt Crisis and Bankruptcy } \\
\text { Law During the Transition: The Case of China }\end{array}$ & David D. Li and Shan Li & December 1995 \\
\hline $\begin{array}{l}\text { No. } 8 \text { Published in: Journal of Comparative } \\
\text { Economics, "A Theory of Ambiguous } \\
\text { Property Rights in Transition Economies: The } \\
\text { Case of the Chinese Non-State Sector." Vol. } \\
\text { 23, No. 1, August 1996, pp. 1-19. }\end{array}$ & David D. Li & June 1996 \\
\hline $\begin{array}{l}\text { No. 7: The Foreign Economic Contract Law of } \\
\text { China: Cases and Analysis }\end{array}$ & Dong-lai Li & June 1993 \\
\hline $\begin{array}{l}\text { No. 3: Bank Privatization in Hungary and the } \\
\text { Magyar Kulkereskedelmi Bank Transaction }\end{array}$ & Roger Kormendi and Karen Schnatterly & May 1996 \\
\hline $\begin{array}{l}\text { Replacing Nos. 1-2 \& 4-6: Journal of } \\
\text { Comparative Economics Symposium on } \\
\text { "Bank Privatization in Central Europe and } \\
\text { Russia." Vol. 25, No. 1, August } 1997 .\end{array}$ & $\begin{array}{l}\text { No. } 1 \text { "Bank Privatization in Transitional } \\
\text { Economies" by Roger Kormendi and } \\
\text { Edward Snyder. No. } 2 \text { "Transactional } \\
\text { Structures of Bank Privatizations in } \\
\text { Central Europe and Russia" by Anna } \\
\text { Meyendorff and Edward A. Snyder. No. } 4 \\
\text { "Bank Privatization in Poland: The Case } \\
\text { of Bank Slaski" by Jeffery Abarbaness and } \\
\text { John Bonin. No. } 5 \text { "Bank Privatization in } \\
\text { Post-Communist Russia: The Case of } \\
\text { Zhilsotsbank" by Jeffery Abarbanell and } \\
\text { Anna Meyendorff and No. } 6 \text { ""The Czech } \\
\text { Republic's Commercial Bank: Komercni } \\
\text { Banka" by Edward A. Snyder and Roger } \\
\text { C. Kormendi. }\end{array}$ & August 1997 \\
\hline
\end{tabular}

Working Papers are available at:

www.wdi.bus.umich.edu 